\title{
PENGARUH KUALITAS PELAYANAN PRIMA (SERVICE EXCELLENCE), PORSI BAGI HASIL DAN TINGKAT PENDAPATAN NASABAH TERHADAP TABUNGAN FIRDAUS PADA PT. BANK ACEH SYARIAH LANGSA
}

\author{
Muhammad Safri Antoni \\ Dosen IAIN Langsa, STAI Aceh Tamiang dan Praktisi Bank Aceh Syariah Langsa
}

\begin{abstract}
ABSTRAK
Penelitian ini bertujuan untuk menguji pengaruh kualitas prima, porsi pembagian laba dan tingkat pendapatan tabungan pelanggan dari tabungan firdaus di PT. Bank Aceh Syariah Langsa secara empiris. Metode yang digunakan untuk analisis data adalah OLS (Ordinary Least Square) dengan model estimasi regresi linier berganda berdasarkan hasil pengelolaan data dengan menggunakan program perangkat lunak Eviews. Dari hasil penelitian, nilai R2 0,851 diperoleh. Ini berarti bahwa sekitar 85,1 persen proporsi variabel independen yang digunakan dapat menjelaskan variasi variabel dependen dalam model itu. Sedangkan sisanya 14,9 persen dijelaskan oleh variabel lain yang tidak digunakan dalam penelitian ini. Sedangkan hasil estimasi menunjukkan bahwa F-hitung lebih besar dari F-tabel (F-hitung $=22,71>\mathrm{F}$-tabel $=2,67$ ) untuk fungsi dari jumlah persamaan penghematan. Ini berarti bahwa semua variabel independen yang digunakan dalam estimasi model analisis ini yaitu layanan, bagi hasil, dan pendapatan secara bersama-sama memberikan pengaruh yang signifikan terhadap jumlah Tabungan Firdaus di PT. Bank Aceh Syariah Langsa. Dengan demikian koefisien layanan menunjukkan nilai 1,028 yang berarti bahwa semakin tinggi tingkat layanan yang sama dengan 1,028 persen, tabungan akan meningkatkan jumlah Tabungan Firdaus di PT. Bank Aceh Syariah Langsa sebesar sekitar 1,028 persen dan bersifat elastis, koefisien pembagian keuntungan menunjukkan nilai 1,425 yang berarti bahwa setiap peningkatan bagi hasil dalam hasil 1,425 persen, tabungan akan meningkatkan jumlah Tabungan Firdaus di PT. Bank Aceh Syariah Langsa untuk sekitar 1,425 persen dan elastis. Koefisien pendapatan menunjukkan nilai 0,737 yang berarti bahwa setiap peningkatan pendapatan sebesar 0,737 persen, tabungan akan meningkatkan jumlah Tabungan Firdaus di PT. Bank Aceh Syariah Langsa sekitar 0,737 persen dan tidak elastis. Layanan adalah salah satu faktor dominan yang mempengaruhi jumlah simpanan di bank syariah, maka itu harus dipertimbangkan oleh setiap bank syariah untuk terus meningkatkan layanan mereka.
\end{abstract}

Kata Kunci: Kualitas Layanan Prima, Porsi Pembagian Laba, Tingkat Pendapatan Tabungan Pelanggan, Tabungan Firdaus di PT. Bank Aceh Syariah Langsa.

\section{Abstract}

This study aimed to test the Influence of Excellent Service Quality, Portion of Profit Sharing and Savings Income Level of Customers of Firdaus Savings at PT. Bank Aceh 
Ihtiyath Vol. 2 No. 2 Desember 2018

Syariah Langsa empirically. The method used for data analysis was OLS (Ordinary Least Square) with double linear regression estimation model based on the results of data processing by using Eviews software program. From the research result, $R^{2}$ value of 0.851 was obtained. This means that approximately 85.1 percent of the proportion of independent variables used could explain the dependent variable variation in that model. Whereas the remaining of 14.9 percent was explained by other variables that were not used in this study. While the estimation results showed that the F-count was greater than the F-table (F-calculated $=22.71>$ F-table $=2.67$ ) for the function of the amount of the savings equation. It means that all independent variables used in the estimation of this analysis model namely service, profit sharing, and income jointly gave significant effect on the amount of Firdaus Savings at PT. Bank Aceh Syariah Langsa. Thus the Coefficient of service showed a value of 1.028 which means that the higher the level of service which was equal to 1.028 percent, the savings would increase the amount of Firdaus Savings at PT. Bank Aceh Syariah Langsa for about 1.028 percent and was elastic, the Coefficient of profit sharing showed a value of 1.425 which means that any increase of profit sharing in the yield of 1.425 percent, the savings would increase the amount of Firdaus Savings at PT. Bank Aceh Syariah Langsa for about 1.425 percent and was elastic. The Coefficient of income showed a value of 0.737 which means that any increase in revenues of 0.737 percent, the savings would increase the amount of Firdaus Savings at PT. Bank Aceh Syariah Langsa for about 0.737 percent and was inelastic. Service is one of the dominant factors that affect the amount of savings in Islamic banks, then it must be put into consideration by any Islamic banks to keep improving their services.

Keyword: Excellent Service Quality, Portion of Profit Sharing, Savings Income Level of Customers, Firdaus Savings at PT. Bank Aceh Syariah Langsa

\section{PENDAHULUAN}

Lembaga keuangan seperti perbankan merupakan instrumen penting dalam memperlancar jalannya pembangunan suatu bangsa. Saat ini perbankan syariah telah memasuki persaingan berskala global, merupakan suatu tantangan yang harus dihadapi dan ditangani oleh bank syariah untuk dapat memberikan kontribusi dalam pembangunan bangsa melalui pemberdayaan ekonomi umat. Banyaknya Bank syariah yang berdiri, konsumen akan dihadapkan pada banyak pilihan akan produk bank syariah yang ditawarkan. Bagi nasabah pelayanan yang bermutu sangat penting. Menurut Royne dalam Tatik Suryani, “kualitas pelayanan menjadi komponen utama karena produk-produk utama bank yaitu kredit merupakan suatu penawaran yang tidak berbeda dan pelayanan bank juga mudah ditiru". Oleh karena itu persaingan akan sangat dipengaruhi oleh kemampuan bank memberikan pelayanan terbaik yang bermutu dibandingkan pesaingnya 
Era sekarang ini yang ditandai oleh revolusi teknologi komunikasi dan informasi mengakibatkan terjadinya perubahan (change) yang luar biasa. Adanya kemudahan yang diperoleh dari komunikasi dan informasi muncul kompetisi yang sangat ketat yang berakibat pelanggan (customer) semakin banyak pilihan dan sangat sulit untuk dipuaskan karena telah terjadi pergeseran yang semula hanya untuk memenuhi kebutuhan, meningkat menjadi harapan (expectation) untuk memenuhi kepuasan. Sehingga bagi perusahaan, kunci kearah profitabilitas bukan lagi volume penjualan melainkan kepuasan jangka panjang bagi pelanggan.

Kualitas dan kepuasan pelanggan berkaitan erat. Kualitas memberikan suatu dorongan kepada pelanggan untuk menjalin ikatan yang kuat dengan perusahaan. Ikatan seperti ini dalam jangka panjang memungkinkan perusahaan untuk memahami dengan seksama harapan pelanggan serta kebutuhan mereka, dengan demikian perusahaan tersebut dapat meningkatkan kepuasan pelanggan dimana perusahaan memaksimumkan pengalaman pelanggan yang menyenangkan dan meminimumkan atau meniadakan pengalaman pelanggan yang kurang menyenangkan. Perusahaan yang gagal memuaskan pelayanannya akan menghadapi masalah yang kompleks. Umumnya pelanggan yang tidak puas akan menyampaikan pengalaman buruknya kepada orang lain dan bisa dibayangkan betapa besarnya kerugian dari kegagalan memuaskan pelanggan. Oleh karena itu, setiap perusahaan jasa wajib merencanakan, mengorganisasikan, mengimplementasikan, dan mengendalikan sistem kualitas sedemikian rupa, sehingga pelayanan dapat memuaskan para pelanggannya.

Penilaian akan kualitas layanan dikembangkan oleh Leonard L. Barry, A. Parasuraman dan Zeithaml yang dikenal dengan service quality (SERVQUAL), yang berdasarkan pada lima dimensi kualitas yaitu tangibles (bukti langsung), reliability (kehandalan), responsiveness (daya tanggap), assurance (jaminan) dan empathy (empati). Kualitas pelayanan merupakan suatu bentuk penilaian Konsumen terhadap tingkat pelayanan yang diterima (perceived service) dengan tingkat layanan yang diharapkan (expected service). Kepuasan pelanggan dalam bidang jasa merupakan elemen penting dan menentukan dalam menumbuhkembangkan perusahaan agar tetap eksis dalam menghadapi persaingan. Demikian pula dengan bisnis perbankan, merupakan bisnis yang berdasarkan pada azas kepercayaan, masalah kualitas layanan (service quality) menjadi faktor penting dalam menentukan keberhasilan bisnis ini. 
Ihtiyath Vol. 2 No. 2 Desember 2018

Keberadaan Bank Syariah di Indonesia menjadi hal yang cukup menarik untuk diteliti dimana Institusi Bank yang dimaksud bukan berbasis pada bunga atau riba tetapi berbasis syariah dengan sistem bagi hasil yang diterapkannya. Ketika hampir semua Bank Konvensional negeri ini mengalami collaps dengan tingginya negative spread karena kewajiban membayar bunga simpanan masyarakat yang jauh lebih tinggi (cost concept) daripada bunga kredit yang diberikan kepada masyarakat, ditambah lagi dengan kredit macet yang membengkak hingga hanya dalam masa lebih setahun terdapat 64 (enam puluh empat) bank yang harus dilikuidasi dan 45 (empat puluh lima) lainnya 'bermasalah' hingga masuk dalam katagori Bank Beku Operasi (BBO) yang harus berada dalam pengawasan BPPN, saat itu pulalah bank-bank syariah yang sudah berjumlah 78 (tujuh puluh delapan) buah bisa bertahan dari goncangan badai krisis dan bahkan mampu untuk tetap eksis. Fenomena menarik tersebut disebabkan karena bank syariah tidak dibebani oleh pembayaran bunga simpanan nasabah. Bank Syariah (BS) hanya membayar bagi hasil yang jumlahnya sesuai dengan tingkat keuntungan yang diperoleh BS. Jika banyak mendapat keuntungan, maka banyak pula yang diberikan kepada penyimpan atau nasabah. Sebaliknya, jika sedikit keuntungan yang diperoleh bank karena terjadinya krisis misalnya, maka sedikit pula bagi hasil yang diberikan kepada penyimpan atau nasabah sesuai dengan porsi bagi hasil yang telah disepakati. Dengan sistem bagi hasil tersebut, maka dapatlah dipahami kenapa bank-bank syariah selamat dari ancaman negative spread ketika terjadi gejolak moneter.

Melihat kenyataan seperti ini, pelaksanaan sistem ekonomi islam dan praktek perbankan non bunga merupakan suatu alternatif yang baik di samping merupakan suatu keharusan dan kewajiban yang mesti dilaksanakan. Kehadiran perbankan syariah di Indonesia cukup berarti bagi kaum muslim Indonesia sebagai bank alternatif tempat melakukan transaksi perdagangan dan keuangan yang sejalan dengan ajaran Islam. Apalagi dengan dikeluarkannya Undang-undang No.21 tahun 2008 tentang tentang perbankan syariah, dimana undang-undang tersebut telah mengatur semua kegiatan perbankan berdasarkan prinsip syariah. Undang-undang ini telah memberikan peluang besar untuk pendirian kantor-kantor bank syariah baru dan pembukaan kantor bank syariah dengan cara konversi dari bank konvensional.

Prinsip operasional perbankan konvensional sama dengan teori klasik yang dikemukan oleh Adam Smith, yang menyatakan bahwa semakin tinggi tingkat suku bunga, maka semakin banyak pula minat masyarakat untuk menabung. Hal inilah yang akan dilihat pada 
perbankan syariah, apakah penerapan tingkat bagi hasil di BS akan lebih menarik animo masyarakat untuk menabung di BS? Begitu pula dengan tingkat pendapatan masyarakat, apakah dengan tingginya tingkat pendapatan masyarakat juga akan lebih menarik animo masyarakat untuk menabung di BS? Seperti yang dikemukan oleh Keynes, bahwa semakin besar tingkat pendapatan yang diterima oleh masyarakat atau seseorang maka semakin besar pula jumlah tabungan yang akan dilakukan oleh masyarakat atau nasabah. Kemudian, di era modern sekarang ini kualitas pelayanan prima (service excellent), bagi hasil yang kompetitif dan pendapatan nasabah tidak bisa diabaikan begitu saja oleh perbankan, terutama perbankan syariah yang mempunyai nilai-nilai spritual yang tinggi dalam menarik animo masyarakat untuk bergabung didalamnya.

Hal itu juga terjadi di PT. Bank Aceh Syariah Langsa sebagai tempat penelitian ini, kualitas pelayanan, bagi hasil serta pendapatan nasabah merupakan hal penting yang perlu diperhatikan. Sesuai dengan slogannya "Insya Allah Berkah dan Bertambah", tentunya segala pelayanan Bank Aceh Syariah harus selalu disesuaikan dengan syariat Islam, apalagi di tengah-tengah persaingan Bank syariah yang semakin pesat, Bank Aceh Syariah dituntut untuk tetap menjaga keberkahan dalam setiap produk dan proses pelayanannya. Masyarakat Islam saat ini semakin kritis, sehingga ketika bank syariah yang selama ini dirindukan kehadirannya ternyata pelayanannya tidak sesuai syariah Islam maka akan berakibat merugikan bank itu sendiri dan menghilangkan kepercayaan masyarakat terhadap bank syariah. Bank Aceh Syariah sebagai salah satu lembaga kepercayaan masyarakat di Provinsi Aceh harus mampu memberikan pelayanan yang berkualitas, bagi hasil yang kompetitif serta harus mengetahui pendapatan nasabah untuk mengetahui keputusan nasabah untuk menabung. Peningkatan kualitas pelayanan Bank Aceh Syariah dilakukan melalui perluasan jaringan maupun dalam bentuk kerja sama dengan lembaga lain. Saat ini, Bank Aceh Syariah memperluas jaringan dengan membuka kantor Cabang, Kantor Capem dan Kantor Kas di setiap Kabupaten / Kota di Provinsi Aceh dan Sumatera Utara. Sedangkan bentuk kerjasama diantaranya dengan PEMDA, Universitas, Sekolah Tinggi, Instansi / BUMN / BUMD, dan lain-lain serta berupa pelayanan ATM dan ATM bersama, Koperasi dan dan juga dengan beberapa yayasan dan Asuransi-asuransi yang ada disekitar wilayah market share-nya masing-masing. Hal ini dilakukan Bank Aceh Syariah sebagai langkah untuk memberikan pelayanan yang memuaskan bagi nasabah. Upaya peningkatan kualitas pelayanan oleh Bank Aceh Syariah bersifat inovatif dan berorientasi pada kepuasan nasabah. Namun masih muncul pertanyaan, apakah hal tersebut telah benarbenar dapat memberikan kepuasan dan keputusan menabung bagi nasabah Bank Aceh 
Ihtiyath Vol. 2 No. 2 Desember 2018

Syariah bila dilihat dari lima dimensi pelayanan yaitu tangibles (bukti langsung), reliability (kehandalan), responsiveness (daya tanggap), assurance (jaminan) dan empathy (empati). Bank Aceh Syariah perlu mengidentifikasi apakah pelayanan, bagi hasil yang kompetitif yang selama ini diberikan telah sesuai dengan harapan nasabah. Hal ini sebagai bukti perhatian Bank Aceh Syariah terhadap kepuasan dan keputusan menabung nasabahnya. Pelayanan, Bagi hasil dan Pendapatan nasabah, dari ketiga faktor ini, manakah yang paling dominan mempengaruhi keputusan nasabah menabung Bank Aceh Syariah Langsa.

\section{KAJIAN LITERATUR}

\section{Pemahaman Konsep Kualit}

\section{Definisi Kualitas}

Definisi kualitas sangat beranekaragam dan mengandung banyak makna. Kualitas adalah sebuah kata yang bagi penyedia jasa merupakan sesuatu yang harus dikerjakan dengan baik. Fandy Tjiptono mendefinisikan "kualitas merupakan suatu kondisi dinamis yang berhubungan dengan produk, jasa, manusia, proses dan lingkungan yang memenuhi atau melebihi harapan". Berdasarkan pengertian kualitas dapat diartikan bahwa kualitas hidup kerja harus merupakan suatu pola pikir (mindset), yang dapat menterjemahkan tuntutan dan kebutuhan pasar konsumen dalam suatu proses manajemen dan proses produksi barang atau jasa terus menerus tanpa hentinya sehingga memenuhi persepsi kualitas pasar konsumen tersebut.

\section{Persepsi Terhadap Kualitas}

Perspektif kualitas yaitu pendekatan yang digunakan untuk mewujudkan kualitas suatu produk/jasa. David dalam Fandy Tjiptono, mengidentifikasikan adanya lima alternatif perspektif kualitas yang biasa digunakan, yaitu:

\section{1). Transcendental Approach}

Kualitas dalam pendekatan ini, dipandang sebagai innate excellence, dimana kualitas dapat dirasakan atau diketahui, tetapi sulit didefinisikan dan dioperasionalisasikan. Sudut pandang ini biasanya diterapkan dalam dunia seni, misalnya seni musik, seni drama, seni tari, dan seni rupa. Meskipun demikian suatu perusahaan dapat mempromosikan produknya melalui pernyataan-pernyataan maupun pesan-pesan komunikasi seperti tempat berbelanja yang menyenangkan (supermarket), elegen (mobil), kecantikan wajah (kosmetik), kelembutan dan kehalusan kulit (sabun mandi), dan lain-lain. Dengan demikian fungsi perencanaan, produksi, dan pelayanan suatu perusahaan sulit sekali 
menggunakan definisi seperti ini sebagai dasar manajemen kualitas

\section{2). Product-based Approach}

Pendekatan ini menganggap bahwa kualitas merupakan karakteristik atau atribut yang dapat dikuantitatifkan dan dapat diukur. Perbedaan dalam kualitas mencerminkan perbedaan dalam jumlah beberapa unsur atau atribut yang dimiliki produk. Karena pandangan ini sangat objektif, maka tidak dapat menjelaskan perbedaan dalam selera, kebutuhan, dan preferensi individual.

\section{3). User-based Approach}

Pendekatan ini didasarkan pada pemikiran bahwa kualitas tergantung pada orang yang memandangnya, sehingga produk yang paling memuaskan preferensi seseorang (misalnya perceived quality) merupakan produk yang berkualitas paling tinggi. Perspektif yang subjektif dan demand-oriented ini juga menyatakan bahwa pelanggan yang berbeda memiliki kebutuhan dan keinginan yang berbeda pula, sehingga kualitas bagi seseorang adalah sama dengan kepuasan maksimum yang dirasakannya.

\section{4). Manufacturing-based Approach}

Perspektif ini bersifat supply-based dan terutama memperhatikan praktik-praktik perekayasaan dan pemanufakturan, serta mendefinisikan kualitas sebagai kesesuaian/ sama dengan persyaratan (conformance torequirements). Dalam sektor jasa, dapat dikatakan bahwa kualitasnya bersifat operations-driven. Pendekatan ini berfokus pada penyesuaian spesifikasi yang dikembangkan secar internal, yang seringkali didorong oleh tujuan peningkatan produktivitas dan penekanan biaya. Jadi yang menentukan kualitas adalah standar-standar yang ditetapkan perusahaan, bukan konsumen yang menggunakannya.

\section{5). Value-based Approach}

Pendekatan ini memandang kualitas dari segi nilai dan harga. Dengan mempertimbangkan trade-off antara kinerja dan harga, kualitas didefinisikan sebagai "affordable excellence". Kualitas dalam perspektif ini bersifat relatif, sehingga produk yang memiliki kualitas paling tinggi belum tentu produk yang paling bernilai. Akan tetapi yang paling bernilai adalah barang atau jasa yang paling tepat dibeli (best-buy).

\section{Konsep Pelayanan Prima (Service Excellent)}

\section{Pengertian Service Excellent}

Service Excellent merupakan derivasi Total Quality Management (TQM) dalam industri 
Ihtiyath Vol. 2 No. 2 Desember 2018

jasa yang mempunyai inti konsep bahwa dalam usaha meningkatkan kualitas jasa perusahaan harus melibatkan komitmen dan kesadaran seluruh level kerja dalam perusahaan yang mana usaha ini harus dilaksanakan terus-menerus sepanjang waktu sehingga akan didapatkan peningkatan penjualan serta pangsa pasar yang lebih luas. Fandy Tjiptono mendefinisikan Pelayanan Prima (Service Excellent) sebagai Sistem manajemen strategi integratif yang melibatkan semua manajer, karyawan serta menggunakan metode kualitatif dan kuantitatif untuk memperbaiki secara berkesinambungan proses-proses organisasi agar dapat memenuhi dan melebihi kebutuhan, keinginan dan harapan konsumen.

\section{Dimensi Pelayanan Prima}

Zeithaml, Parasuraman, dan Berry telah mengidentifikasi lima dimensi pelayanan yang berkualitas dan prima, yaitu:

1). Bukti langsung (tangibles)

Definisi bukti langsung dalam Rambat Lupiyoadi yaitu "kemampuan suatu perusahaan dalam menunjukkan eksistensi kepada pihak eksternal. Penampilan dan kemampuan sarana dan prasarana fisik perusahaan dan keadaan lingkungan sekitarnya adalah bukti nyata dari pelayanan yang diberikan oleh pemberi jasa, yang meliputi fasilitas fisik (gedung, gudang, dan lain sebagainya), perlengkapan dan peralatan yang dipergunakan (teknologi), serta penampilan pegawainya". Bukti langsung dalam Fandy Tjiptono adalah "bukti fisik dari jasa, bisa berupa fisik, peralatan yang dipergunakan, representasi fisik dari jasa (misalnya, kartu kredit plastik)". Sedangkan Philip Kotler mengungkapkan bahwa bukti langsung adalah "fasilitas dan peralatan fisik serta penampilan karyawan yang professional".

2). Kehandalan (reliability)

Kehandalan dalam Rambat Lupiyoadi adalah "kemampuan perusahaan untuk memberikan pelayanan sesuai yang dijanjikan secara akurat dan terpercaya. Kinerja harus sesuai dengan harapan pelanggan yang berarti ketepatan waktu, pelayanan yang sama, untuk semua pelanggan tanpa kesalahan, sikap yang simpatik, dan dengan akurasi yang tinggi". Fandy Tjiptono mendefinisikan kehandalan adalah "mencakup dua hal pokok, yaitu konsistensi kerja (performance) dan kemampuan untuk dipercaya (dependability). Hal ini berarti perusahaan memberikan jasanya secara tepat semenjak saat pertama (right the first time). Selain itu juga berarti bahwa perusahaan yang bersangkutan memenuhi janjinya, misalnya menyampaikan jasanya sesuai dengan jadwal yang disepakati”. Secara singkat definisi kehandalan dalam Fandy Tjiptono adalah "kemampuan memberikan pe- 
layanan yang dijanjikan dengan segera, akurat, dan memuaskan".

\section{3). Daya tanggap (responsiveness)}

Menurut Rambat Lupiyoadi daya tanggap adalah "suatu kemauan untuk membantu dan memberikan pelayanan yang cepat (responsif) dan tepat kepada pelanggan, dengan penyampaian informasi yang jelas. Membiarkan konsumen menunggu tanpa adanya suatu alasan yang jelas menyebabkan persepsi yang negatif dalam kualitas pelayanan". Sedangkan menurut Fandy Tjiptono daya tanggap adalah "keinginan para staf untuk membantu para pelanggan dan memberikan pelayanan dengan tanggap".

\section{4). Jaminan (assurance)}

Definisi jaminan dalam Rambat Lupiyoadi yaitu "pengetahuan, kesopansantunan, dan kemampuan para pegawai perusahaan untuk menumbuhkan rasa percaya para pelanggan kepada perusahaan. Terdiri dari beberapa komponen antara lain komunikasi (communication), kredibilitas (credibility), keamanan (security), kompetensi (competence), dan sopan santun (courtesy)". Senada dengan pengertian di atas Fandy Tjiptono mendefinisikan jaminan adalah "mencakup pengetahuan kemampuan, kesopanan, dan sifat dapat dipercaya yang dimiliki para staff, bebas dari bahaya, risiko, atau keragu-raguan". Sedangkan menurut Philip Kotler jaminan adalah "pengetahuan dan kesopanan dari karyawan, dan kemampuan untuk mendapatkan kepercayaan dan keyakinan".

\section{5). Empati (empathy)}

Rambat Lupiyoadi menerangkan empati adalah "memberikan perhatian yang tulus dan bersifat individual atau pribadi yang diberikan kepada para pelanggan dengan berupaya memahami keinginan konsumen. Dimana suatu perusahaan diharapkan memiliki pengertian dan pengetahuan tentang pelanggan, memahami kebutuhan pelanggan secara spesifik, serta memiliki waktu pengoperasian yang nyaman bagi pelanggan". Menurut Fandy Tjiptono empati adalah "kemudahan dalam melakukan hubungan, komunikasi yang baik, perhatian pribadi, dan memahami kebutuhan para pelanggan". Lebih singkat lagi Philip Kotler mendefinisikan empati adalah tingkat perhatian pribadi terhadap para pelanggan".

\section{Kualitas Pelayanan dalam Perspektif Islam}

Islam mengajarkan bila ingin memberikan hasil usaha baik berupa barang maupun pelayanan/jasa hendaknya memberikan yang berkualitas, jangan memberikan yang buruk 
Ihtiyath Vol. 2 No. 2 Desember 2018

atau tidak berkualitas kepada orang lain. Seperti dijelaskan dalam Al-Quran surat Al-Baqarah ayat 267:

Artinya: "Hai orang-orang yang beriman, nafkahkanlah (dijalan Allah) sebagian dari hasil usahamu yang baik-baik dan sebagian dari apa yang kami keluarkan dari bumi untuk kamu dan janganlah kamu memilih yang buruk-buruk lalu kamu nafkahkan darinya padahal kamu sendiri tidak mau mengambilnya melainkan dengan memicingkan mata terhadapnya. Dan ketahuilah bahwa Allah Maha Kaya lagi Maha Terpuji"

Salah satu dimensi kualitas pelayanan adalah tangibles (bukti langsung) yang berupa fasilitas fisik meliputi gedung, mesin ATM dan sarana prasarana lainnya. Menurut mazhab mainstream dalam Adiwarman Karim menjelaskan perbedaan ekonomi Islam dan konvensional terletak dalam menyelesaikan masalah. Dilema sumber daya yang terbatas versus keinginan yang tak terbatas memaksa manusia untuk melakukan pilihan-pilihan atas keinginannya. Dalam ekonomi konvensional, pilihan didasarkan atas selera pribadi masingmasing. Manusia boleh mempertimbangkan tuntunan agama, boleh juga mengabaikan. Sedangkan dalam ekonomi Islam, keputusan pilihan ini tidak dapat dilakukan semaunya saja, semua perilaku harus dipandu oleh Allah lewat Al-Qur'an dan Hadis. Fasilitas dalam Islam dan konvensional juga tidak mengalami perbedaan yang signifikan, perbedaannya hanya terletak pada proses penggunaannya yang mana ketika pelaku bisnis memberikan pelayanan dalam bentuk fisik hendaknya tidak menonjolkan kemewahan. Sebagaimana dijelaskan dalam Al Qur'an surat At-Takaatsur ayat 1-5, yaitu :

Artinya: "Bermegah-megahan telah melalaikan kamu, sampai kamu masuk kedalam kubur. Janganlah begitu, kelak kamu akan mengetahui (akibat perbuatanmu itu) dan janganlah begitu, kelak kamu akan mengetahui. Janganlah begitu, jika kamu mengetahui dengan pengetahuan yang yakin".

Fasilitas yang diberikan dalam melakukan pelayanan akan terlihat semu tanpa adanya reliability (kehandalan) dari pelaku bisnis. Kehandalan dalam pelayanan dapat dilihat dari ketepatan dalam memenuhi janji secara akurat dan terpercaya. Allah sangat menganjurkan setiap umatnya untuk selalu menepati janji yang telah ditetapkan seperti dijelaskan dalam Al Qur'an surat An-Nahl ayat 91, yaitu:

Artinya: "Dan tepatilah perjanjian dengan Allah apabila kamu berjanji dan janganlah kamu 226 
membatalkan sumpah-sumpah ( $\mathrm{mu}$ ) itu sesudah meneguhkannya, sedang kamu telah menjadikan Allah sebagai saksimu (terhadap sumpah-sumpah itu), sesungguhnya Allah mengetahui apa yang kamu perbuat".

Ayat diatas menjelaskan bahwa setiap manusia diwajibkan menepati janji yang telah ditetapkan, demikian juga dengan pelaku bisnis baik janji yang ditetapkan secara langsung maupun janji-janji dalam bentuk promosi, semuanya harus ditepati dan sesuai dengan kenyataan. Penawaran ketika promosi atau iklan yang tidak sesuai dengan kenyataan berarti telah mengingkari janji yang ditetapkan dan hal ini telah mengandung unsure penipuan yang akan merugikan konsumen. Pelanggan lebih loyal pada perusahaan yang selalu menepati janji daripada perusahaan yang banyak menawarkan promosi mewah tapi tidak sesuai dengan kenyataan.

Kualitas pelayanan juga dapat dilihat dari responsiveness (daya tanggap) karyawan, yang mana karyawan memiliki kemauan dan memberikan pelayanan yang cepat dan tepat kepada pelanggan, memberikan pelayanan dengan cepat dan tepat menunjukkan pelaku bisnis yang profesional. Thorik Gunara, dkk menjelaskan bahwa dalam soul marketing kecepatan dalam bergerak adalah hal yang utama. Pemanfaatan waktu secara efektif benar-benar menjadi hal yang bersifat esensial. Pelaku bisnis yang selalu tanggap maka akan melahirkan sikap inovatif dan tidak ada waktu yang terbuang. Islam menganjurkan setiap pelaku bisnis untuk bersikap profesional yakni dapat bekerja dengan cepat dan tepat sehingga tidak menyia-nyiakan amanat yang menjadi tanggungjawabnya.

Ketika pelaku bisnis bekerja memberikan pelayanan dengan keahliannya (kompeten) maka akan bekerja dengan tanggap (cepat dan tepat) sehingga pelanggan akan memperoleh kepuasan. Profesionalisme dan kompetensi terhadap sebuah pekerjaan adalah dua hal yang saling berkaitan, namun kadang ada individu yang memaksakan diri mengerjakan sebuah pekerjaan yang bukan bidangnya (sesuatu yang dikuasai dengan baik) sehingga yang terjadi adalah kerugian, baik dari sisi waktu pelaksanaan pekerjaan maupun kerugian materil.

Adanya assurance (jaminan) juga dapat menunjukkan nilai plus tersendiri bagi perusahaan terhadap pelayanan yang diberikan. Jaminan ini dapat ditunjukkan melalui pengetahuan, kesopansantunan, rasa aman, rasa percaya, bebas dari bahaya dan resiko yang dapat diberikan karyawan kepada pelanggan. Adiwarman Karim menjelaskan bahwa baik buruk- 
Ihtiyath Vol. 2 No. 2 Desember 2018

nya perilaku bisnis para pengusaha menentukan sukses-gagalnya bisnis yang dijalankan. Al Qur'an Surat Ali Imran ayat 159 menjelaskan:

Artinya: "Maka disebabkan rahmat dari Allah-lah kamu berlaku lemah lembut terhadap mereka. Sekiranya kamu bersikap keras lagi berhati kasar, tentulah mereka menjauhkan diri dari sekelilingmu. Karena itu, maafkanlah mereka; mohonkanlah mapun bagi mereka, dan bermusyawarahlah dengan mereka dalam urusan itu. Kemudian apabila kamu telah membulatkan tekad, maka bertawakallah kepada Allah. Sesuangguhnya Allah menyukai orang-orang yang bertawakal kepadaNya".

Berdasarkan ayat diatas, jelas bahwa setiap manusia dituntunkan untuk berlaku lemah lembut agar orang lain merasakan kenyamanan bila berada disampingnya. Apalagi dalam pelayanan yang mana konsumen banyak pilihan, bila pelaku bisnis tidak mampu memberikan rasa aman dengan kelemahlembutannya maka konsumen akan berpindah ke perusahaan lain. Pelaku bisnis dalam memberikan pelayanan harus menghilangkan jauh-jauh sikap keras hati dan harus memiliki sifat pemaaf kepada pelanggan agar pelanggan terhindar dari rasa takut, tidak percaya, dan perasaan adanya bahaya dari pelayanan yang diterima.

Selain empat hal diatas, kualitas pelayanan juga dapat dilihat dari faktor empathy (empati) yang dapat diberikan oleh karyawan kepada pelanggan/konsumen. Sikap empati ditunjukkan melalui kemudahan dalam melakukan hubungan, komunikasi yang baik, perhatian pribadi, dan memahami kebutuhan para pelanggan. Dalam Islam sikap empati merupakan wujud dari kemauan karyawan untuk memberikan kemudahan pada pelanggan dengan senang hati dalam melakukan transaksi, disaat pelanggan mengalami kesulitan maka karyawan siap membantu.

\section{BAGI HASIL}

Bagi hasil adalah suatu sistem pembagian keuntungan (profit sharing) dan kerugian (loss sharing) secara bersama antara masing-masing pihak yang terkait. Islam mendorong praktek bagi hasil serta mengharamkan riba. Keduanya sama-sama memberi keuntungan bagi pemilik dana, namun keduanya mempunyai perbedaan yang sangat nyata. Perbedaan itu dapat di jelaskan dalam tabel berikut : 
Tabel 1: Perbedaan Antara Bunga dan Bagi Hasil

\begin{tabular}{|c|c|}
\hline Bunga & Bagi Hasil \\
\hline $\begin{array}{l}\text { Penentuan bunga dibuat pada waktu } \\
\text { akad dengan asumsi harus selalu } \\
\text { untung }\end{array}$ & $\begin{array}{l}\text { Penentuan besarnya rasio/nisbah bagi } \\
\text { hasil dibuat pada waktu akad dengan } \\
\text { berpedoman pada kemungkinan untung }\end{array}$ \\
\hline $\begin{array}{l}\text { Pembayaran bunga tetap seperti } \\
\text { yang dijanjikan tanpa pertimbangan } \\
\text { apakah proyek yang dijalankan oleh } \\
\text { nihak nasabah untung atau ruoj }\end{array}$ & $\begin{array}{l}\text { Bagi hasil tergantung pada keuntungan } \\
\text { proyek yang dijalankan. Bila usaha merugi, } \\
\text { kerugian akan ditanggung bersama oleh } \\
\text { kedua belah nihak }\end{array}$ \\
\hline $\begin{array}{l}\text { meningkat sekalipun jumlah } \\
\text { keuntungan berlipat atau keadaan } \\
\text { ekonomi sedang 'booming, }\end{array}$ & $\begin{array}{l}\text { Jumlah pembagian laba meningkat sesuai } \\
\text { dengan peningkatan jumlah pendapatan }\end{array}$ \\
\hline $\begin{array}{l}\text { Eksistensi bunga diragukan (kalau } \\
\text { tidak dikecam) oleh semua agama } \\
\text { termasuk Islam. }\end{array}$ & $\begin{array}{l}\text { Tidak ada yang meragukan keabsahan } \\
\text { bagi hasil. }\end{array}$ \\
\hline
\end{tabular}

Sebagaimana diketahui, bank yang beroprasi berdasarkan prinsip-prinsip Islam menawarkan sistem bagi hasil kepada nasabahnya. Artinya, selain pembagian untung dan rugi sama-sama ditanggung oleh kedua belah pihak, dan juga dapat dipahami bahwa keuntungan yang akan diperoleh nasabah bisa berubah-ubah, semuanya tergantung pada pendapatan atau keuntungan yang diperoleh bank syari'ah. Besarnya prsentase bagi hasil sudah ditetapkan oleh pihak bank. Namun, biasanya masih membuka ruang tawar-menawar dalam batas yang wajar. Perhitungan bagi hasil di bank syariah ada dua jenis; pertama Profit/Loss Sharing. Dalam sistem ini, besar-kecil pendapatan bagi hasil yang diterima nasabah tergantung keuntungan bank. Kedua Revenue Sharing. Dalam sistem ini, penentuan bagi hasil akan tergantung pada pendapatan kotor bank. Perbankan syariah di Indonesia umumnya menerapkan sistem Revenue Sharing. Pola ini dapat memperkecil kerugian bagi nasabah, Hanya saja jika bagi hasil didasarkan pada profit sharing, maka presentase bagi hasil untuk nasabah akan jauh lebih tinggi. Prinsip bagi hasil dalam perbankan syariah menjadi prinsip utama dan terpenting, karena keuntungan (bagi hasil) merupakan balasan (upah) atas usaha dan modal, besar-kecilnya pun tergantung pada keduanya. Dalam qawaid fiqhiyah (kaidah fiqh) dikatakan "algharam bil ghanam" (ada untung rugi), prinsip ini memenuhi prinsip keadilan ekonomi. Dan didalam kaedah bisnis dikatakan bahwa setiap yang akan menghasilkan keuntungan yang besar, terkandung juga risiko yang besar (high risk, high return). Bagi pihak yang akan menjalankan prinsip ini, maka harus membuat kesepakatan diawal yang berkaitan dengan usaha yang akan dijalankan dan menetapkan nisbah (bagian) bagi hasil masing-masing pihak menurut 
Ihtiyath Vol. 2 No. 2 Desember 2018

cara pembagiannya. Usaha yang akan dijalankan merupakan usaha-usaha yang dibenarkan menurut syariah, tidak boleh ditanamkan pada usaha yang di haramkan. Yang akan dibagi hasilkan adalah keuntungan bersih dari usaha tersebut tetapi boleh juga dibuat kesepakatan diantara dua pihak jika bagi hasil diperhitungkan dari total sales. Karena yang dibagi hasilkan merupakan suatu keuntungan, maka besar kecilnya nominal keuntungan akan mengalami turun-naik, tergantung dari usaha dan kesungguhan dalam mengelola usaha tersebut. Inti dari pada prinsip bank syariah adalah sistem bagi hasil yang mengatur hubungan bank dengan nasabah layaknya sebagai hubungan mitra usaha, demikian pula hubungan antara bank dengan deposan.

\section{Pendapatan}

\section{Pengertian Pendapatan}

Committee on Terminology mendefinisikan Revenue sebagai hasil dari penjualan barang/ pemberian jasa yang dibebankan kepada langganan, atau mereka yang menerima jasa. Menurut Harahap suatu penghasilan akan diakui sebagai penghasilan pada periode kapan kegiatan utama yang perlu untuk menciptakan dan menjual barang dan jasa itu telah selesai. Waktu yang dimaksud disini ada empat alternatif:

1). Selama produksi.

2). Pada saaat proses produksi selesai.

3). Pada saat penjualan.

4). Pada saat penagihan kas.

Keempat alternatif ini sama-sama dipakai dalam pengakuan pendapatan selama proses produksi berlangsung diterapkan pada proyek pembangunan jangka panjang. Pada saat selesainya produksi dapat diterapkan pada kegiatan pertanian atau pertambangan, pada saat penjualan dipakai untuk barang perdagangan, pada saat penagihan kas diterapkan pada metode penjualan angsuran. Pendapatan merupakan kenaikan kotor dalam asset atau penurunan dalam liabilitas atau gabungan dari keduanya selama periode yang dipilih oleh pernyataan pendapatan yang berakibat dari investasi, perdagangan, memberikan jasa atau aktivitas lain yang bertujuan meraih keuntungan. Menurut Sistem neraca Sosial Ekonomi (SNSE) Indonesia, pola pendapatan rumah tangga terdiri dari upah dan gaji, keuntungan usaha rumah tangga (mikro) yang tidak berbadan hukum dan penerimaan transfer. Pendapatan adalah arus masuk atau penambahan nilai atas harta suatu kesa- 
tuan atau penyelesaian suatu kewajiban atau kombinasi keduanya selama satu periode dari penyerahan atau produksi barang, penyerahan jasa, atau aktivitas lain yang merupakan operasi utama kesatuan tersebut. Dalam PSAK No. 23 Ikatan Akuntansi Indonesia menyatakan bahwa pendapatan adalah arus masuk bruto dari manfaat ekonomi yang timbul dari aktivitas normal perusahaan selama satu periode bila arus masuk itu mengakibatkan kenaikan ekuitas yang tidak berasal dari kontribusi penanaman modal. Menurut Estes pendapatan adalah arus masuk sumber daya ke dalam suatu perusahaan dalam suatu periode dari penjualan barang atau hasil penjualan jasa, pendapatan tidak mencakup sumber daya yang diterima dari sumber-sumber selain dari operasi seperti penjualan aktiva tetap, penerbitan saham atau pinjaman. Menurut Undang Undang Republik Indonesia No. 10 tahun 1994 tentang pajak penghasilan (PPh), pendapatan atau penghasilan dirumuskan sebagai berikut : "Yang menjadi objek pajak adalah penghasilan, yaitu setiap tambahan kemampuan ekonomis yang diterima atau diperoleh wajib pajak, baik yang berasal dari Indonesia maupun dari luar Indonesia yang dapat dipakai untuk konsumsi atau untuk menambah kekayaan wajib pajak yang bersangkutan dengan nama dan dalam bentuk apapun. Menurut Sigit penghasilan atau pendapatan adalah kebalikan dari biaya. Tiap-tiap memperoleh penghasilan atau pendapatan tentu disertai dengan wujud penerimaan benda, harta kekayaan atau hak. Tidak ada sesuatu pendapatan bertambah tidak dengan mengakibatkan pertambahan pada aktiva, apakah pertambahan itu ke dalam kas, tagihan, wesel tagih ataupun hak. Pengertian pendapatan yang lain menurut Baridwan pendapatan adalah aliran masuk harta-harta (aktiva) yang timbul dari penyerahan barang atau jasa yang dilakukan oleh suatu unit usaha selama satu periode tertentu.

Berdasarkan definisi-definisi diatas pendapatan dalam penelitian ini adalah aliran masuk kas yang dihitung dari jumlah yang dibebankan kepada langganan untuk barang-barang yang diserahkan atau jasa-jasa baik berupa laba, tagihan ataupun hak setelah dikurangi biaya-biaya yang berasal dari hasil penggunaan pinjaman yang diberikan oleh lembaga keuangan atau lainnya.

\section{Macam-macam Pendapatan}

Macam-macam pendapatan ditinjau dari bentuknya ada tiga macam yaitu:

1). Pendapatan berupa uang adalah segala penghasilan berupa uang yang biasanya diterima sebagai balas jasa prestasi sumber-sumber utama yaitu gaji dan upah.

2). Pendapatan berupa barang adalah segala penghasilan yang bersifat reguler 
Ihtiyath Vol. 2 No. 2 Desember 2018

dan biasa, akan tetapi tidak selalu berbentuk balas jasa dan diterimakan dalam bentuk barang, misalnya gaji yang diwujudkan dalam bentuk beras, pengobatan, perumahan.

3). Pendapatan selain penerimaan uang dan barang adalah segala penerimaan yang bersifat transfer redistribusi dan biasanya membawa perubahan dalam keuangan rumah tangga, misalnya penjualan barang-barang yang dipakai pinjaman uang, hasil undian, warisan, penagihan hutang.

Pendapatan menurut perolehannya dapat diartikan menjadi dua, yaitu:

1). Pendapatan kotor yaitu pendapatan yang diperoleh sebelum dikurangi dengan pengeluaran dan biaya lain.

2). Pendapatan bersih yaitu pendapatan yang diperoleh setelah dikurangi dengan pengeluaran dan biaya lain

Pendapatan ditinjau dari bidang kegiatannya dibagi menjadi dua yaitu:

1). Pendapatan sektor formal yaitu segala pendapatan baik berupa barang maupun uang yang bersifat reguler dan diterimakan biasanya sebagai balas jasa atau kontra prestasi di sektor formal yang meliputi : pendapatan yang berupa uang, misalnya gaji, upah, dan hasil investasi dan pendapatan yang berupa keahlian yang tinggi dapat meningkatkan efisiensi dan efektivitas kerja dan akhirnya akan berpengaruh terhadap penghasilan.

2). Pendapatan sektor non formal, yaitu segala pendapatan baik berupa barang maupun uang yang bersifat regular dan diterimakan biasanya sebagai balas jasa atau kontra prestasi di sektor non formal seperti pendapatan usaha sampingan toko, usaha sampingan lain yang bisa menghasilkan uang.

Faktor-faktor Yang Mempengaruhi Pendapatan

Faktor-faktor yang mempengaruhi pendapatan menurut Bintari dan Suprihatin yaitu:

1). Kesempatan kerja yang terbatas.

2). Kecakapan dan keahlian.

3). Motivasi.

4). Keuletan bekerja.

5). Banyak sedikitnya modal yang dipegunakan. 


\section{TABUNGAN FIRDAUS IB (FITRAH DALAM USAHA)}

Tabungan Firdaus merupakan akronim dari fitrah dalam usaha syariah, yang bermakna bahwa dengan tabungan ini bank dan nasabah akan melakukan kerjasama secara syariah yang fitrah yang tentunya pada akhirnya akan membawa hasil yang halal, berkah, dan bertambah.

a. Tabungan Firdaus pada Bank Aceh Syariah diperuntukkan bagi perorangan yang menggunakan prinsip mudharabah (bagi hasil) dimana dana yang diinvestasikan oleh nasabah dapat dipergunakan oleh Bank (mudharib) dengan imbalan bagi hasi bagi nasabah (shahibul maal). Tabungan firdaus menggunakan akad mudharabah muthlaqah yang berarti pihak bank diberi kuasa penuh untuk menjalankan usahanya tanpa batasan sepanjang memenuhi syarat-syarat syariah dan tidak terikat dengan waktu, tempat, jenis usaha, dan nasabah pelanggannya

b. Sebagai bukti penabung, Bank menerbitkan buku tabungan atas nama penabung, Bank juga dapat menerbitkan kartu ATM sesuai permintaan penabung

c. Apabila buku tabungan hilang, penabung wajib melaporkan kehilangan tersebut ke Kantor Bank Aceh Syariah penerbit buku tabungan

d. Tabungan Firdaus dapat digunakan sebagai Jaminan Pembiayaan atau Pinjaman pada Bank Aceh Syariah

e. Apabila terjadi selisih saldo antara buku tabungan dengan catatan Bank, maka saldo yang dipakai adalah saldo yang ada pada Bank

f. Bank berhak mengadakan perubahan-perubahan pada syarat-syarat umum tanpa pemberitahuan terlebih dahulu dan perubahan tersebut mulai mengikat sejak saat diberlakukannya

g. Pajak atas bagi hasil/bonus tabungan ditanggung oleh penabung.

h. Tabungan Firdaus merupakan produk unggulan PT. Bank Aceh Syariah.

\section{PENYETORAN DAN PENARIKAN TABUNGAN FIRDAUS}

a) Penyetoran dan Penarikan dapat dilakukan saat kas buka pada semua kantor PT. Bank Aceh Syariah

b) Setoran pertama minimal Rp. 50.000.,- (Lima puluh ribu rupiah) dan setoran selanjutnya sekurang-kurangnya Rp. 10.000,- (sepuluh ribu rupiah)

c) Penarikan dapat dilakukan setiap hari kerja selama kantor buka dengan saldo tersisa sekurang-kurangnya Rp. 50.000,- (lima puluh ribu rupiah)

d) Penarikan dapat dilakukan di Kantor Pusat, Kantor Cabang, Cabang Pembantu, 
Ihtiyath Vol. 2 No. 2 Desember 2018

Kantor Kas PT. Bank Aceh Syariah di seluruh Provinsi Aceh dan SUMUT

e) Penarikan yang dilakukan oleh bukan penabung sendiri, harus dilengkapi dengan surat kuasa dari penabung dengan bermaterai secukupnya.

1) Penutupan Tabungan Firdaus

a) Penabung berhak setiap saat menutup rekening tabungannya selama kantor buka pada cabang penerbit

b) Penutupan secara otomatis karena saldo menjadi nihil akan dilakukan oleh PT. Bank Aceh syariah tanpa pemberitahuan kepada penabung.

\section{HIPOTESIS}

Berdasarkan uraian diatas, maka dapat dikembangkan Hipotesis penelitian sebagai berikut :

$\mathrm{Ha}=$ Terdapat pengaruh yang signifikan kualitas pelayanan prima (service excellent), porsi bagi hasil dan tingkat pendapatan nasabah pada tabungan Firdaus di PT. Bank Aceh Syariah Langsa

Ho = Tidak terdapat pengaruh yang signifikan kualitas pelayanan prima (service excellent), porsi bagi hasil dan tingkat pendapatan nasabah pada tabungan Firdaus di PT. Bank Aceh Syariah Langsa

Sehingga model penelitian yang dibangun dalam kajian ini adalah sebagai berikut:

Gambar 1. Kerangka Pemikiran

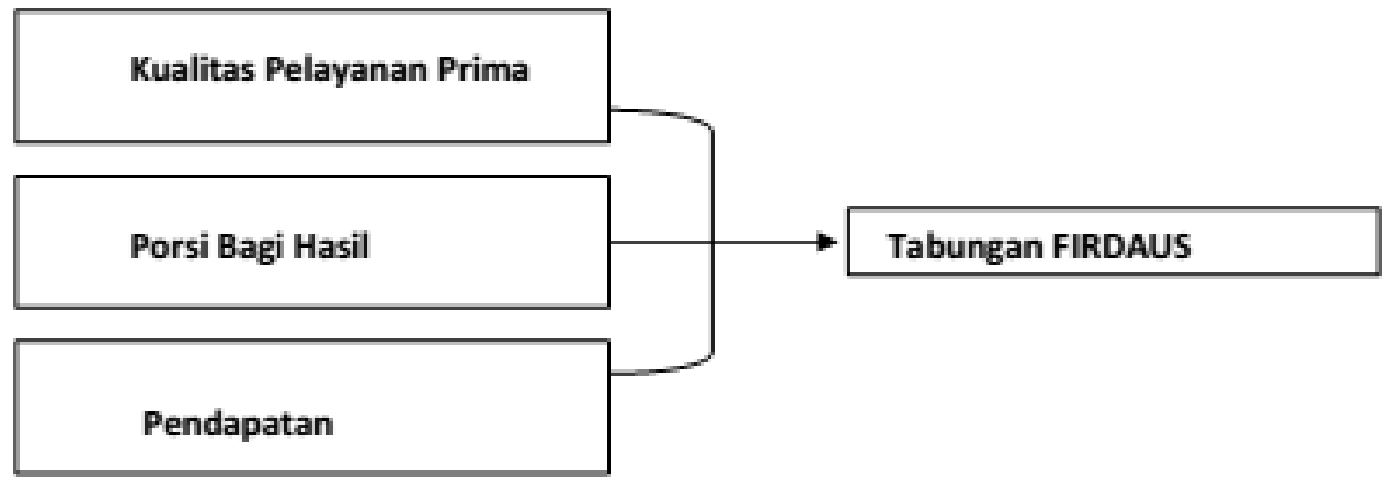

\section{METODE PENELITIAN}

Penelitian ini dilakukan dengan menggunakan pendekatan survey, dengan jenis penelitian deskriptif kuantitatif. Pendekatan survey adalah kegiatan mengumpulkan data se- 
banyak-banyaknya mengenai fakta-fakta yang merupakan pendukung terhadap penelitian, dengan maksud untuk mengetahui status, gejala, menentukan kesamaan status dengan cara membandingkan dengan standar yang sudah dipilih dan atau ditentukan. Van Dalen mengemukakan bahwa survey bukanlah hanya bermaksud mengetahui status gejala, tetapi juga bermaksud menentukan kesamaan status dengan cara membandingkan dengan standar yang sudah dipilih atau ditentukan. Di samping itu juga, untuk membuktikan atau membenarkan suatu hipotesis. Penelitian ini menggunakan data primer dan data sekunder yang dikumpulkan untuk mencapai tujuan penelitian.

\section{Data primer}

Menurut Nur Indriantoro dan Bambang Supomo, "data primer merupakan sumber data penelitian yang diperoleh secara langsung dari sumber asli (tidak melalui media perantara)". Data primer dalam penelitian ini diperoleh langsung dari hasil wawancara (interview) dan dengan menyebar kuesioner kepada para pemakai tabungan FIRDAUS Bank Aceh Syariah Langsa.

\section{Data sekunder}

Sedangkan data sekunder menurut Nur Indriantoro dan Bambang Supomo merupakan "sumber data penelitian yang diperoleh peneliti secara tidak langsung melalui media perantara (diperoleh dan dicatat oleh pihak lain)". Data sekunder dalam penelitian ini diperoleh dari perusahaan yang dapat dilihat pada dokumentasi perusahaan, buku-buku referensi dan informasi lain yang berhubungan dengan penelitian.

\section{Definisi Operasional}

1. Pelayanan yang dimaksud disini terbagi menjadi 5 indikator yaitu tangible, reliability, responsiveness, assurance dan emphathy.

2. Pendapatan adalah penghasilan berupa uang yang biasanya diterima sebagai balas jasa prestasi sumber-sumber utama yaitu gaji dan upah.

3. Bagi Hasil adalah Porsi bagi hasil yang akan didistribusikan $\mathrm{x}$ nisbah nasabah $\mathrm{x}$ saldo rata-rata deposan/total DPK (Mudharabah) atau dari equivalen bagi hasil.

4. Tabungan adalah investasi yang dilakukan oleh nasabah sebagai pemilik dana (sahibul mal) dan bank sebagai pihak yang bebas tanpa pembatasan dari pemilik dana dan menyalurkan dana nasabah tersebut dalam bentuk pembiayaan yang tidak bertentangan dengan syariah 


\section{Populasi dan Sampel}

Menurut Djarwanto dan Pangestu Subagyo, “populasi adalah jumlah dari keseluruhan obyek (satuan-satuan/individu-individu) yang karakteristiknya hendak diduga". Populasi dalam penelitian ini adalah seluruh nasabah yang menggunakan tabungan FIRDAUS di Bank Aceh Syariah Langsa. Untuk menentukan minimal sampel yang dibutuhkan jika ukuran populasi diketahui, dapat digunakan rumus Slovin sebagai berikut:

$$
\mathrm{n}=\frac{\mathrm{N}}{1+\mathrm{Ne}^{2}}
$$

Dimana:

$\mathrm{n} \quad=$ Ukuran sampel.

$\mathrm{N} \quad=$ Ukuran populasi

e $=$ Persen kelonggaran ketidaktelitian karena kesalahan pengambilan sampel yang masih dapat ditolerir atau diinginkan.

Dengan jumlah nasabah sampai dengan tanggal 30 September 2018 yaitu sebanyak 42.553 orang. Dan tingkat kesalahan (e) sebesar Rp. 10\%, maka besarnya sampel adalah sebagai berikut:

$\mathrm{n}=\frac{42553}{1+42553(0,10)^{2}}$

n dibulatkan menjadi 100 nasabah

Sampel menurut Djarwanto dan Pangestu Subagyo adalah "sebagian dari populasi yang karakteristiknya hendak diselidiki, dan dianggap bisa mewakili keseluruhan populasi (jumlahnya lebih sedikit daripada jumlah populasi)".

Kemudian untuk menentukan siapa yang akan dijadikan sampel dilakukan dengan metode accidental sampling, yaitu para nasabah Bank Aceh Syariah Langsa yang bertemu dengan peneliti di lokasi penelitian. Accisental Sampling adalah teknik penentuan sampel berdasarkan kebetulan, yaitu siapa saja yang secara kebetulan/incidental bertemu dengan peneliti dapat digunakan sebagai sampel, bila dipandang orang yang kebetulan ditemui itu cocok sebagai sumber data. 


\section{METODE PENGUJIAN DATA}

\section{Uji Instrumen.}

\section{Validitas}

Validitas data merupakan suatu ukuran yang menunjukkan tingkat kesahihan suatu instrument. Instrumen yang sahih memiliki validitas tinggi. Instrumen dikatakan sahih apabila mampu mengukur apa yang diinginkan, mampu mengungkapkan data dari variabel yang diteliti secara tepat, tinggi rendahnya validitas instrumen menunjukkan sejauh mana data yang terkumpul tidak menyimpang dari gambaran validitas yang dimaksud. Teknik yang digunakan untuk uji validitas adalah teknik korelasi product moment dari Pearson dengan rumus:

$$
r y x=\frac{n \sum X Y-\left(\sum X\right)\left(\sum Y\right)}{\sqrt{\left\{n \sum X^{2}-\left(\sum X\right)^{2}\right\}\left\{n \sum Y^{2}-\left(\sum Y\right)^{2}\right\}}}
$$

Dimana:

rxy $=$ Korelasi Product Moment Pearson Item dengan nilai sikap

$\mathrm{X}=$ Total nilai keseluruhan subyek per item

$\mathrm{Y}=$ Total nilai sikap per subyek

$\mathrm{n}$ = jumlah subyek

Untuk menentukan validitas digunakan teknik korelasi positif dengan kriteria (Skor total) serta korelasi yang tinggi, menunjukkan bahwa item tersebut mempunyai validitas yang tinggi pula.

\section{Reliabilitas}

Reliabilitas menunjukkan sejauh mana suatu instrument dapat memberikan hasil pengukuran yang konsisten apabila pengukuran diulang dua kali atau lebih. Menurut Suharsimi uji reliabilitas bisa dilakukan dengan menggunakan teknik Alpha-Cronbach, yaitu dengan rumus:

$\dot{\boldsymbol{r}}=\frac{k}{(k-1)}\left\{1-\frac{\sum S^{2}}{S_{t}^{2}}\right\}$ 
Dimana :

ri $=$ Reliabilitas instrumen

$\mathrm{k}$ = Banyaknya butir pertanyaan

$1=$ Bilangan konstan

$\sum \mathrm{S} 1^{2}=$ Jumlah varians butir

$\mathrm{S} 1^{2}=$ Varians total

Kriteria uji reliabilitas instrumen yang baik adalah yang makin mendekati 1. Rumus Alpha digunakan untuk mencari reabilitas instrumen yang skronya bukan 1 atau 0, misalnya angket atau suatu bentuk uraian.

\section{Uji Signifikansi Statistik}

\section{Uji Parsial}

Uji parsial ini digunakan untuk mengetahui besarnya pengaruh faktor dimensi kualitas pelayanan (tangibles, reliability, responsiveness, assurance, empathy) dengan kepuasan nasabah secara individual. Menurut Djarwanto dan Pangestu S. langkah-langkah untuk uji parsial adalah sebagai berikut:

1). Menentukan hipotesa nihil dan hipotesa alternative Ho: $\beta=0$ : Secara individu signifikan dimensi kualitas pelayanan tidak berpengaruh terhadap kepuasan nasabah

Ha : $\beta \neq 0$ : Secara individu signifikan dimensi kualitas pelayanan berpengaruh terhadap kepuasan nasabah

2). Level of signifikan $\alpha=5 \%$

3). Kriteri pengujian (role of test)

\section{Daerah terima}

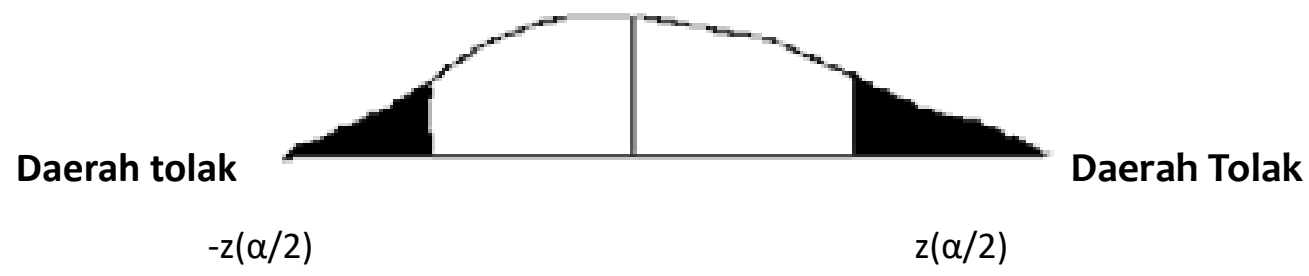


Ho diterima apabila $-z(\alpha / 2) \leq z \leq z(\alpha / 2)$

Ho ditolak apabila $z>z(\alpha / 2)$ atau $z<-z(\alpha / 2)$

4). Perhitungan nilai $z$

$$
Z=\frac{X^{-1}}{\frac{S}{n}}
$$

Keterangan :

$\mathrm{X}=$ rata-rata sampel

$\mathrm{s}=$ variance populasi

$\mathrm{n}=$ besarnya sampel

\section{KESIMPULAN}

Dengan membandingkan $z$ dengan $z(\alpha / 2)$ dapat diketahui tingkat signifikan dimensi kualitas pelayanan (tangibles, reliability, responsiveness, assurance, empathy) dengan kepuasan nasabah.

\section{Uji F}

Pengujian ini dilakukan untuk mengetahui adanya pengaruh dimensi kualitas pelayanan (tangibles, reliability, responsiveness, assurance, empathy) dengan kepuasan nasabah secara bersamaan. Menurut Djarwanto dan Pangestu S. langkah-langkah untuk uji F adalah sebagai berikut:

1). Menentukan hipotesis nihil dan hipotesis alternatif

Ho: $\beta=0$ : Secara signifikan dimensi kualitas pelayanan tidak

berpengaruh terhadap kepuasan nasabah

Ha: $\beta \neq 0$ : Secara signifikan dimensi kualitas pelayanan berpengaruh terhadap kepuasan nasabah

2). Level of signifikan $\alpha=5 \%$

3). Kriteria pengujian (role of test) 


\section{Daerah tolak}

Daerah terima

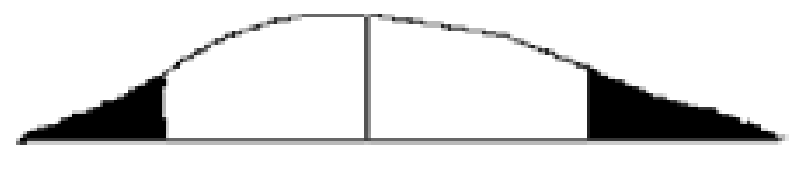

$$
F \alpha ;(k ; n-k-1)
$$

Ho diterima apabila $\mathrm{F}$ hitung $\leq \mathrm{F}$ tabel

Ho ditolak apabila $\mathrm{F}$ hitung $>\mathrm{F}$ tabel

\section{Perhitungan Nilai F}

$$
F=\frac{J K_{r o g} / k}{J K_{r e s} /(n-k-1)}
$$

Keterangan:

$$
\begin{array}{llll}
\mathrm{F} \text { Hitung } & =\text { Nilai F hitung } & \mathrm{n} & =\text { banyaknya kasus } \\
\mathrm{K} & =\text { jumlah prediktor } & \mathrm{JK}_{\text {Reg }} & =\text { jumlah kuadrat regresi } \\
\mathrm{JK}_{\text {Res }} & =\text { jumlah kuadrat residu }
\end{array}
$$

Dengan membandingkan $\mathrm{F}$ hitung dengan $\mathrm{F}$ tabel dapat diketahui hubungan dimensi kualitas pelayanan dengan kepuasan nasabah.

\section{Analisis koefisien determinasi (R2)}

Adalah angka yang menunjukkan proporsi variabel dependen yang dijelaskan oleh variabel independen. R2 mampu memberikan informasi mengenai variasi nilai variabel dependen yang dapat dijelaskan oleh model regresi yang digunakan. Koefisien determinasi menurut Djarwanto dan Pangestu S. dihitung dengan rumus sebagai berikut:

$$
R^{2}=\frac{b_{1} \Sigma y x_{1}+b_{1} \Sigma y x_{2}+b n \Sigma y x_{n}}{\Sigma y^{2}}
$$

Apabila koefisien determinasi ( $R 2$ ) mendekati angka satu (1) berarti terdapat hubungan yang kuat. 


\section{Uji Asumsi Klasik}

\section{Normalitas}

Tujuan uji normalitas adalah ingin mengetahui apakah distribusi sebuah data mengikuti atau mendekati distribusi normal. Pengujian normalitas dapat dilakukan dengan uji Jarque-Bera, yaitu :

$$
\int B=n\left[\frac{5^{2}}{6}+\frac{(K-3)^{2}}{24}\right]
$$

Dimana:

$\mathrm{S} \quad=$ menunjukkan Skewness (kemencengan)

$\mathrm{K}=$ menunjukkan kurtosis (keruncingan)

Suatu distribusi dikatakan normal. bila nilai JB lebih kecil daripada nilai Chi Square $\left(x^{2}\right)$

\section{Multikolinearitas}

Penyimpangan multikolinearitas artinya antarvariabel independen yang terdapat dalam model memiliki hubungan yang sempurna atau mendekati sempurna. Secara matematis pengukuran multikolinearitas dapat dirumuskan:

$$
\begin{aligned}
& \operatorname{VlF}\left[b l^{\Delta}\right]=\frac{1}{\left(1-R^{2}\right)} \\
& \mathrm{R} 2=\text { Koefisien Determinasi }
\end{aligned}
$$

Persamaan variabel bebas jika memiliki nilai yang semakin besar maka menunjukkan multikolinearitas akan lebih sederhana. Bila nilai faktor varian bebas lebih dari 10, maka terjadi multikolinearitas.

\section{Heteroskedastisitas}

Penyimpangan heteroskedastisitas menurut Algifari artinya varians variabel dalam model tidak sama (konstan). Pengujian heteroskedastisitas dilakukan dengan menggunakan teknik dari Park, yaitu dengan melakukan analisis regresi dengan menggunakan nilai residual sebagai variabel dependen yang diperoleh dari analisis regresi biasa. 


$$
\operatorname{Ln} e=a+b 1 \times 1+b 2 \times 2+b 3 \times 3+b 4 \times 4+b 5 \times 5
$$

Jika semua variabel independen signifikan secara statistik, maka dalam model terdapat heteroskedastisitas atau membandingkan nilai t hitung dan nilai t tabel, bila t hitung lebih kecil dari t tabel maka tidak terjadi heteroskedastisitas.

\section{Uji Kriteria Kebermaknaan Ekonomi}

Uji kriteria "a priori" ekonomi dilakukan dengan cara membandingkan kesesuaian tanda antara koefisien parameter regresi dengan teori yang bersangkutan. Jika tanda koefisien parameter regresi sesuai dengan prinsip-prinsip teori ekonomi, maka parameter tersebut telah lolos dari pengujian.

\section{Pembahasan \\ Deskripsi Data}

Dalam penelitian ini ada 100 kuesioner yang disebarkan kepada nasabah PT. Bank Aceh Syariah Langsa. Untuk memberikan pemahaman terhadap demografis responden yang diteliti dalam penelitian ini maka dapat diuraikan sebagai berikut :

Tabel 2: Gambaran Responden Mengenai Jenis Kelamin

\begin{tabular}{|c|c|c|}
\hline Jenis Kelamin & Jumlah & Persentase \\
\hline Laki-laki & 55 & $55 \%$ \\
\hline Perempuan & 45 & $45 \%$ \\
\hline Jumlah & 100 & $100 \%$ \\
\hline
\end{tabular}

Sumber : Data diolah, 2018

Berdasarkan tabel 2 di atas dapat ditemukan bahwa jumlah responden berjenis kelamin laki-laki berjumlah 55 responden (55\%), sedangkan yang berjenis kelamin perempuan berjumlah 45 responden (45\%), terlihat bahwasanya responden berjenis kelamin laki-laki yang mendominasi dalam penelitian ini.

Tabel 3: Gambaran Responden Mengenai Pendidikan

\begin{tabular}{|c|c|c|}
\hline Pendidikan & Jumlah & Persentase \\
\hline$\leq$ SMA & 31 & $31 \%$ \\
\hline Diploma & 22 & $22 \%$ \\
\hline S-1 & 36 & $36 \%$ \\
\hline S-2 & 8 & $8 \%$ \\
\hline S-3 & 3 & $3 \%$ \\
\hline Jumlah & 100 & $100 \%$ \\
\hline
\end{tabular}

Sumber : Data diolah, 2018 
Dari tabel 3 di atas dapat dikemukakan bahwa jumlah responden yang berpendidikan $\leq$ SMA berjumlah 31 responden (31\%), responden yang berpendidikan Diploma berjumlah 22 (22\%), yang berpendidikan S-1 berjumlah 36 responden (36\%), yang berpendidikan S-2 berjumlah 8 responden (8\%) dan responden yang berpendidikan $\geq \mathrm{S}-3$ berjumlah 3 responden (3\%). Dengan demikian responden yang berpendidikan S-1 yang mendominasi dalam penelitian ini.

\section{Tabel 4: Gambaran Responden Mengenai Usia}

\begin{tabular}{|c|c|c|}
\hline Usia & Jumlah & Persentase \\
\hline $17-20$ Tahun & 11 & $11 \%$ \\
\hline $21-30$ Tahun & 19 & $19 \%$ \\
\hline $31-40$ Tahun & 37 & $37 \%$ \\
\hline $41-50$ Tahun & 23 & $23 \%$ \\
\hline$>50$ Tahun & 10 & $10 \%$ \\
\hline Jumlah & 100 & $100 \%$ \\
\hline
\end{tabular}

Sumber : Data diolah, 2018

Berdasarkan tabel 4 di atas dapat dikemukakan bahwa jumlah responden yang berusia 17 - 20 tahun berjumlah 11 responden (11\%), yang berusia 21 - 30 tahun berjumlah 19 respondeng (19\%), yang berusia 31 - 40 tahun berjumlah 37 responden (37\%), yang berusia 41 - 50 tahun berjumlah 23 responden (23\%), dan yang berusia > 50 tahun berjumlah 10 responden (10\%). Dengan demikian responden yang berusia 31 - 40 tahun yang mendominasi dalam penelitian ini.

Tabel 5: Gambaran Responden Mengenai Pekerjaan

\begin{tabular}{|c|c|c|}
\hline Pekerjaan & Jumlah & Persentase \\
\hline Guru/Dosen/PNS & 42 & $42 \%$ \\
\hline Karyawan Swasta & 23 & $23 \%$ \\
\hline Wiraswasta & 27 & $27 \%$ \\
\hline Lainnya & 8 & $8 \%$ \\
\hline Jumlahh & 100 & $100 \%$ \\
\hline
\end{tabular}

Sumber : Data diolah, 2018

Berdasarkan tabel 5 di atas, dapat dikemukakan bahwa jumlah responden yang bekerja sebagai Guru/Dosen/PNS berjumlah 42 responden (42\%), yang bekerja sebagai Karyawan Swasta berjumlah 23 responden (23\%), sebagai Wiraswasta berjumlah 27 responden (27\%), yang bekerja sebagai diluar pekerjaan yang disebut di atas (pelajar, ibu rumah tangga, dan lain-lain) berjumlah 8 responden (8\%). Dengan demikian responden yang bekerja sebagai Guru/Dosen/PNS dan wiraswasta yang mendominasi dalam penelitian ini. 
Ihtiyath Vol. 2 No. 2 Desember 2018

\section{Perkembangan Bagi Hasil}

Bagi hasil merupakan pengaruh yang besar terhadap peningkatan jumlah tabungan Bank Syariah dimana semakin besar tingkat bagi hasil suatu Bank maka semakin tinggi minat menabung nasabah dengan meningkatnya minat menabung di Bank syariah maka semakin tinggi jumlah tabungan bank syariah. Oleh karena itu, persentase tingkat bagi hasil disajikan dalam tabel 6, sebagai berikut :

Tabel 6: Persentase Bagi Hasil

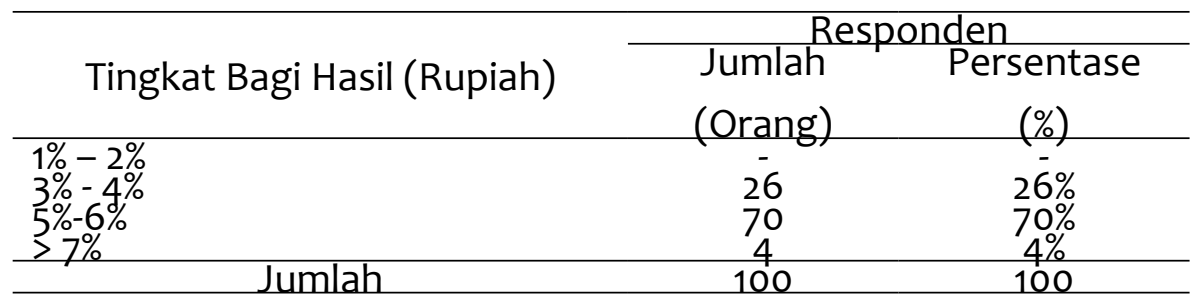

Berdasarkan dari tabel 6 di atas dapat diketahui bahwa bagi hasil tabungan FIRDAUS di PT. Bank Aceh Syariah Langsa mayoritas memiliki bagi hasil sebesar 5\% - 6\% sebanyak 49 persen.

\section{Tingkat Pendapatan}

Pendapatan merupakan pengaruh yang sangat besar terhadap peningkatan jumlah tabungan Bank Syariah dimana semakin besar tingkat pendapatan seorang nasabah maka semakin besar jumlah tabungan yang akan ditabungkan di Bank Syariah tersebut, Oleh karena itu, persentase tingkat pendapatan dapat disajikan dalam tabel 7 sebagai berikut :

Tabel 7: Persentase Pendapatan Nasabah

\begin{tabular}{ccc}
\hline & \multicolumn{2}{c}{ Responden } \\
\cline { 2 - 3 } Pendapatan (Rupiah) & Jumlah & Persentase \\
& (Orang) & $(\%)$ \\
Rp. 500.000-Rp. 1.000 .000 & 16 & 16 \\
Rp. 1.100.000- Rp. 2.000 .000 & 43 & 43 \\
Rp. 2.100.000-Rp. 3.000 .000 & 7 & 7 \\
\hline Rp. 3.100.000 & 34 & 34 \\
\hline jumlah & 100 & 100 \\
\hline
\end{tabular}

Berdasarkan dari tabel 7 di atas dapat diketahui bahwa pendapatan nasabah tabungan FIRDAUS di PT. Bank Aceh Syariah Langsa yang memiliki persentase tertinggi adalah Rp. $1.100 .000-2.000 .000$ sebesar 43 persen, sedangkan tingkat persentase terendah adalah 
Muhammad Safri Antoni: Pengaruh Kualitas Pelayanan yang memiliki tingkat pendapatan sebesar Rp.2.100.000 - Rp.3.000.000 sebesar 7 persen.

\section{Hasil Uji Kualitas Data Validitas}

Berdasarkan tabel tabulasi skor jawaban responden terhadap variabel pelayanan maka instrumen yang terdiri dari 22 butir (item) dari pertanyaan yang dijawab oleh responden dilakukan pengujian validitas dari tiap butir yang digunakan. Pengujian dilakukan dengan mengkorelasikan skor tiap butir dengan skor total yang merupakan jumlah tiap skor tiap butir jawaban responden. Validitas suatu butir pertanyaan dapat dilihat pada hasil output dengan menggunakan Uji Korelasi Pearson Product Moment. Menilai kevaliditasan masing - masing butir pertanyaan dapat dilihat dari nilai pearson correlation atau dilihat dari probability masing - masing butir pertanyaan. Suatu butir pertanyaan dikatakan valid jika pearson correlation > dari $r$ table dan Probabilty < dari 0,05. Dengan menggunakan jumlah responden sebanyak 100 orang, maka nilai r-tabel dapat diperoleh melalui df (degree of freedom) $=\mathrm{n}-\mathrm{k} . \mathrm{n}$ merupakan sampel dan $\mathrm{k}$ merupakan jumlah variabel bebas dan terikat. Jadi $\mathrm{df}=100-4=96$, maka $r$ tabel $=0,205$. Butir pertanyaan dikatakan valid jika nilai $r$ hitung yang merupakan dari nilai pearson corelation $>$ dari $r$ table. Dari hasil pengolahan data maka diketahui tingkat kevaliditasan masing - masing butir pertanyaan adalah:

Tabel 8: Validitas Pencitraan

\begin{tabular}{|c|c|c|c|c|}
\hline & $\begin{array}{l}\text { Pearson Corelation } \\
\text { (r hitung) }\end{array}$ & r-table & $\begin{array}{l}\text { Probability } \\
(a=5 \%)\end{array}$ & \\
\hline Btr 1 & .533 & 0.205 & & Valid \\
\hline Btr 2 & .746 & 0.205 & .000 & Valid \\
\hline Btr 3 & .847 & 0.205 & .000 & Valid \\
\hline$\frac{B \operatorname{tr} 4}{B \operatorname{tr} 5}$ & $\begin{array}{l}.408 \\
.658\end{array}$ & $\frac{0.205}{0.205}$ & $\begin{array}{l}.025 \\
.000\end{array}$ & $\begin{array}{l}\text { Validid } \\
\text { Valid }\end{array}$ \\
\hline Btr 6 & .581 & 0.205 & .001 & Valid \\
\hline Btr 7 & .547 & 0.205 & .002 & Valid \\
\hline Btr 8 & .696 & 0.205 & .000 & Valid \\
\hline $\begin{array}{l}\text { Btr } 9 \\
\text { Btr } 10\end{array}$ & .681 & 0.205 & .000 & Valid \\
\hline $\begin{array}{l}\text { Btr } 10 \\
\text { Btr } 11\end{array}$ & .765 & 0.205 & .000 & Valid \\
\hline $\begin{array}{l}\text { Btr } 11 \\
\text { Btr } 12\end{array}$ & .814 & 0.205 & .000 & \\
\hline Btr 13 & .001 & $\begin{array}{l}0.205 \\
0.205\end{array}$ & $\begin{array}{l}.000 \\
.000\end{array}$ & $\begin{array}{l}\text { Valluc } \\
\text { Valid }\end{array}$ \\
\hline Btr 14 & .779 & 0.205 & .000 & Valid \\
\hline $\operatorname{Btr} 15$ & .529 & 0.205 & .003 & Valid \\
\hline Btr 16 & .711 & 0.205 & .000 & Valid \\
\hline Btr 17 & $\frac{.607}{572}$ & 0.205 & .000 & \\
\hline$\frac{\text { Btr } 18}{B \operatorname{tr} 10}$ & .522 & 0.205 & .003 & Valid \\
\hline$\frac{B \operatorname{tr} 19}{B \operatorname{tr} 20}$ & $\begin{array}{l}.810 \\
.810\end{array}$ & $\frac{0.205}{0.205}$ & . .000 & $\begin{array}{l}\text { Valluc } \\
\text { Valid }\end{array}$ \\
\hline Btr 21 & .361 & 0.205 & .050 & Valid \\
\hline
\end{tabular}


Ihtiyath Vol. 2 No. 2 Desember 2018

\begin{tabular}{|l|l|l|l|l|}
\hline Btr 22 & .398 & 0.205 & .029 & Valid \\
\hline
\end{tabular}

Hasil analisis variabel pencitraan menunjukkan adanya 22 butir pertanyaan yang diajukan adalah valid, berdasarkan hasil tersebut maka dapat dikatakan bahwa butir pertanyaan dapat digunakan karena r-hitung lebih besar dari r-tabel sehingga dapat dikatakan memenuhi syarat validitas.

\section{Reliabilitas}

Reliabilitas (keandalan) merupakan ukuran suatu kestabilan dan konsistensi responden dalam menjawab hal yang berkaitan dengan kostruk - konstruk pertanyaan yang merupakan dimensi suatu variabel dan disusun dalam suatu bentuk kuisioner. Uji reliabilitas dapat dilakukan secara bersama - sama terhadap seluruh butir pertanyaan untuk lebih dari satu variabel, namun sebaiknya uji reliabilitas dilakukan pada masing - masing variabel pada lembar kerja yang berbeda sehingga dapat diketahui konstruk variabel mana yang tidak reliabel. Reliabilitas suatu konstruk variabel dikatakan baik jika memiliki nilai Cronbach's Alpa > dari 0,60. Dari hasil pengolahan uji maka diketahui hasil dari keluaran data yaitu:

\section{Tabel 9: Variabel Pelayanan}

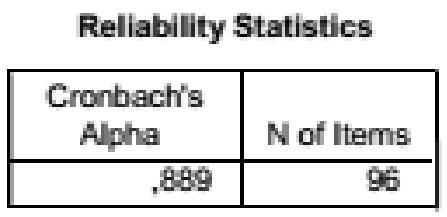

Dari tabel 9 data di atas menunjukkan tabel reliabilitas statistic memiliki nilai Cronbach's Alpha sebesar 0,889 > 0,60. Dapat dikatakan bahwa konstruk pertanyaan yang merupakan dimensi variabel Pelayanan adalah sangat reliabel.

\section{Pengujian Hasil Estimasi Model Penelitian}

Untuk melihat apakah Hasil estimasi model penelitian tersebut di atas bermakna secara teoritis (theoritically meaningful) dan nyata secara statistik (statistically significant), dipakai tiga kriteria pengujian, yaitu uji kriteria statistik (first order test), uji kriteria ekonometrika dan uji kriteria kebermaknaan ekonomi (second order test), sebagai berikut: 


\section{Tabel 10: Hasil Estimasi Persamaan Jumlah Tabungan}

Dependent Variable: $\operatorname{LOG}(\mathrm{S})$

Method: Least Squares

Date: 11/11/18 Time: 09:26

Sample: 1100

Included observations: 100

\begin{tabular}{|c|c|c|c|c|}
\hline & & Std. Error & t-Statistic & Prol \\
\hline $\begin{array}{c}\text { LOG(P्PYN) } \\
\text { LOE(BH } \\
\text { LOG(PNDPTN) }\end{array}$ & $\begin{array}{r}-2.48 \\
1.02 \\
1.42 \\
0.73\end{array}$ & $\begin{array}{l}2.332189 \\
0.406176 \\
0.530881 \\
0.107504\end{array}$ & $\begin{array}{r}-1.065920 \\
2.532339 \\
2.684923 \\
6.861636 \\
\end{array}$ & $\begin{array}{l}0.2891 \\
0.0130 \\
0.0085 \\
0.0000\end{array}$ \\
\hline $\begin{array}{l}\text { R-squared } \\
\text { Adjusted } R \\
\text { S.E. of regr }\end{array}$ & $\begin{array}{l}0.851590 \\
0.846952 \\
0.673991\end{array}$ & \multicolumn{2}{|c|}{$\begin{array}{l}\text { Mean dependent var } \\
\text { S.D. dependent var } \\
\text { Akaike info criterion } \\
\text { Schwarz criterion }\end{array}$} & $\begin{array}{r}14.90872 \\
1.722822\end{array}$ \\
\hline $\begin{array}{l}\text { Sum squared resi } \\
\text { Log likelihood } \\
\text { Durbin-Watson st }\end{array}$ & $\begin{array}{r}43.60935 \\
-100.3989 \\
1.712173 \\
\end{array}$ & $\begin{array}{l}\text { Schwarz } \\
\text { F-statistic } \\
\text { Prob(F-st }\end{array}$ & iterion & 22.7 \\
\hline
\end{tabular}

\section{Uji Kriteria Statistik}

Uji kriteria statistik dilakukan berdasarkan prinsip-prinsip statistik yang meliputi pengujian kebermaknaan regresi secara parsial, pengujian kebermaknaan regresi secara serentak, dan pengujian ketepatan letak taksiran garis regresi.

\section{1). Uji Regresi Secara Parsial}

Pengujian koefisien regresi secara parsial bertujuan untuk mengetahui pengaruh dari masing-masing variabel bebas (independent variable) terhadap variabel terikat (dependent variable). Pengujian ini dilakukan dengan menggunakan uji t (t-test).

Kebermaknaan secara parsial dengan menggunakan uji t (t-test) dengan tingkat signifkansi 5 persen $(\alpha=5 \%$ ), serta derajat kebebasan ( $\delta$ ) adalah $n-k=100-4=96$, maka diperoleh nilai kritis t-tabel sebesar 1,984 atau dengan menggunakan prob. Selanjutnya dengan membandingkan nilai t-hitung dan t-label dapat dinyatakan bahwa :

Pelayanan mempunyai pengaruh positif dan signifikan terhadap jumlah tabungan FIRDAUS di PT. Bank Aceh Syariah Langsa, karena t-ratio sebesar 2,532 lebih besar dari t-tabel sebesar 1,984 atau prob sebesar 0,01 signifikan < 0,05. Dengan demikian pelayanan berpengaruh singifikan terhadap jumlah tabungan FIRDAUS di PT. Bank Aceh Syariah Langsa.

Bagi hasil mempunyai pengaruh positif dan signifikan terhadap jumlah tabungan FIRDAUS di PT. Bank Aceh Syariah Langsa, karena t-ratio sebesar 2,684 lebih besar dari t-tabel sebesar 1,984 atau prob sebesar 0,000 signifikan < 0,05. Dengan demikian bagi hasil berpengaruh positif dan signifikan terhadap jumlah tabungan FIRDAUS di PT. Bank Aceh 
Syariah Langsa.

Pendapatan mempunyai pengaruh positif dan signifikan terhadap jumlah tabungan FIRDAUS di PT. Bank Aceh Syariah Langsa, karena t-ratio sebesar 6,861 lebih besar dari t-tabel sebesar 1,984 atau prob sebesar 0,000 signifikan < 0,05. Dengan demikian pendapatan berpengaruh singifikan terhadap jumlah tabungan FIRDAUS di PT. Bank Aceh Syariah Langsa.

\section{2). Uji Koefisien Regresi Secara Serentak}

Pengujian koefisien regresi secara serentak bertujuan untuk mengetahui apakah semua variabel bebas yang digunakan dalam estimasi model secara bersama-sama mempunyai pengaruh yang signifikan (berarti) terhadap variabel terikat. Pengujian ini dapat dilakukan dengan menggunakan uji Fisher (F-Test) dengan cara membandingkan F-hitung dengan F-tabel.

Dengan menggunakan tingkat signifikansi 5 persen ( $\alpha=5 \%$ ) serta derajat kebebasan $(\delta f) \mathrm{N}$ $=\mathrm{n}-\mathrm{k}=100-4=96$, maka diperoleh nilai kritis F-tabel sebesar 2.67. Hasil estimasi menunjukkan F-hitung lebih besar dari F-tabel (F-hitung = 22,71 > F-tabel = 2,67) untuk fungsi persamaan jumlah tabungan, Ini berarti bahwa semua variabel bebas (independent variable) yang digunakan dalam estimasi model analisis ini, yaitu pelayanan, bagi hasil, dan pendapatan secara bersama-sama berpengaruh secara signifikan (berarti) terhadap jumlah tabungan FIRDAUS di PT. Bank Aceh Syariah Langsa.

\section{3). Uji Ketepatan Letak Taksiran Garis Regresi (Goodness of Fit)}

Uji ketepatan letak taksiran garis regresi ini, dapat ditunjukkan oleh besarnya nilai koefisien determinasi $\left(R^{2}\right)$, yang besarnya antara nol dan satu $\left(0<R^{2}<1\right)$. Semakin tinggi nilai $R^{2}$ (mendekati 1 ), berarti estimasi model regresi yang dihasilkan semakin mendekati keadaan yang sebenarnya (goodness of fit) atau menunjukkan tepatnya letak taksiran garis regresi yang diperoleh.

Dari hasil estimasi model persamaan jumlah tabungan firdaus diperoleh nilai $\mathrm{R}^{2}$ sebesar 0.851. Ini berarti, bahwa sebesar 85,1 persen proporsi variabel-variabel bebas yang digunakan mampu menjelaskan variasi variabel terikat dalam model tersebut, sedangkan sisanya yang hanya sebesar 14,9 persen dijelaskan oleh variabel lain yang tidak digunakan dalam penelitian ini. Nilai $\mathrm{R}^{2}$ ini memperlihatkan estimasi model yang dihasilkan dari pe- 
nelitian ini cukup memperlihatkan keadaan yang sebenarnya (goodness of tit) atau cukup kuat untuk dipercaya.

\section{Uji Kriteria Ekonometrika}

Uji kriteria ekonometrika yang dilakukan terhadap hasil estimasi model dalam penelitian ini adalah uji gejala normalitas, multikolinearitas dan Heteroskedastisitas sebagai berikut:

1). Uji Gejala Normalitas

Dengan menggunakan uji $\chi^{2}$ dengan tingkat signifikan 5 persen $(\alpha=5 \%)$ serta derajat kebebasan $(\delta f)$ adalah $n-k=100-5=95$. Fungsi persamaan jumlah tabungan mempunyai $\chi^{2}$ hitung sebesar 0,370 atau prob. sebesar 0,831, maka dalam penelitian ini bersifat normal. Uji normalitas dapat juga menggunakan Jarque-Bera normalitas test.

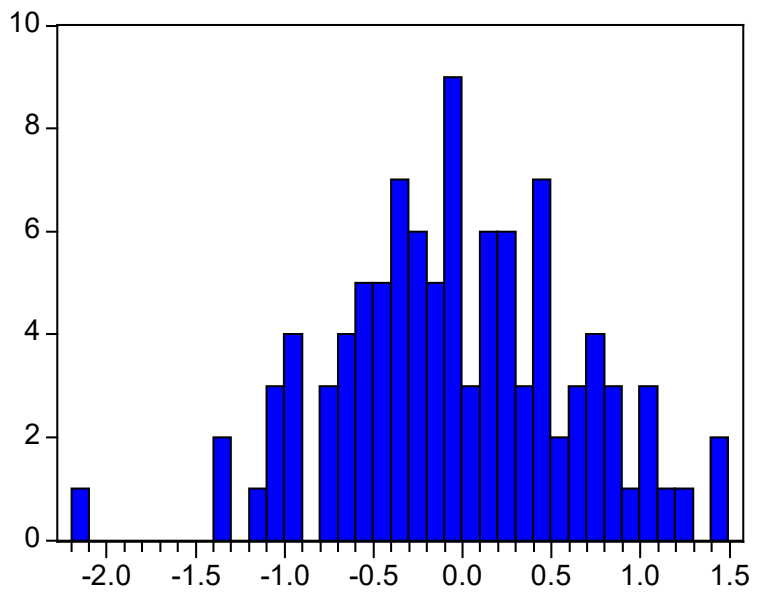

\begin{tabular}{|lr|}
\hline \multicolumn{2}{|l|}{ Series: Standardized Residuals } \\
Sample 1 100 \\
Observations & 100 \\
& \\
Mean & -0.028793 \\
Median & -0.059080 \\
Maximum & 1.492391 \\
Minimum & -2.142082 \\
Std. Dev. & 0.663069 \\
Skewness & -0.120551 \\
Kurtosis & 3.175191 \\
& \\
Jarque-Bera & 0.370092 \\
Probability & 0.831066 \\
\hline
\end{tabular}

\section{Gambar 2: Uji Gejala Normalitas}

Dari gambar 2 dimana prob. $\chi^{2}$ hitung sebesar 0,831 lebih besar dari $5 \%(0,05)$ yang berarti bahwa data dalam penelitian ini bersifat normal.

\section{2). Uji Gejala Multikolinearitas}

Pengujian gejala multikolinearitas dilakukan untuk mendeteksi apakah terdapat hubungan (korelasi) yang sempurna antara variabel bebas yang satu dengan variabel bebas yang lainnya dalam model. Apabila ada, berarti terdapat gejala multikolinearitas yang akan menyebabkan standar error-nya semakin besar, sehingga kemungkinan besar inter- 
Ihtiyath Vol. 2 No. 2 Desember 2018

pretasi hasil atau kesimpulan yang diambil akan keliru. Maka hasil uji gejala multikolinearitas dapat dilihat tabel dibawah ini :

Tabel 11: Uji Gejala Multikolinearitas

\begin{tabular}{|c|c|c|c|}
\hline & LOG(PLYN) & $\operatorname{LOG}(\mathrm{BH})$ & $\operatorname{LOG}(\mathrm{PND})$ \\
\hline LOG(PLYN) & 1 & & \\
\hline $\operatorname{LOG}(\mathrm{BH})$ & -0.0140 & 1 & \\
\hline LOG(PND) & 0.1687 & 0.0041 & 1 \\
\hline
\end{tabular}

Sumber: Hasil penelitian

Dari Tabel 11 terlihat bahwa $r^{2}$ parsial masing-masing variabel bebasnya ternyata jauh lebih kecil dibandingkan $\mathrm{R}^{2}$ pada estimasi model regresi yang diperoleh. Jadi dapat disimpulkan bahwa hasil estimasi model tersebut bebas dari gejala multikolinearitas.

\section{3). Uji Heterokedastisitas}

\section{Tabel 12: Uji Gejala Heterokedastisitas}

White Heteroskedasticity Test:

\begin{tabular}{lrll} 
& & \\
\hline F-statistic & 2.012710 & Probability & 0.071662 \\
Obs*R-squared & 11.49285 & Probability & 0.074287 \\
\hline
\end{tabular}

Berdasarkan hasil analisis output, Nilai probability dari nilai Obs* $\mathrm{R}$ squared sebesar 0,074 $>$ dari 0,05 . maka dapat disimpulkan model diatas lolos uji heteroskedastisitas.

\section{Uji Kriteria Kebermaknaan Ekonomi}

Uji kriteria "a priori" ekonomi dilakukan dengan cara membandingkan kesesuaian tanda antara koefisien parameter regresi dengan teori yang bersangkutan. Jika tanda koefisien parameter regresi sesuai dengan prinsip-prinsip teori ekonomi, maka parameter tersebut telah lolos dari pengujian. Maka persamaan Jumlah tabungan FIRDAUS sebagai berikut:

$\operatorname{LOG}(S)=-2.485+1.028 * \operatorname{LOG}(P L Y N)+1.425 * \operatorname{LOG}(B H)+0.737 * \operatorname{LOG}($ PNDPTN $)$

Dari hasil estimasi model regresi seperti ditunjukkan pada Tabel 13 dapat diketahui bahwa tanda koefisien parameter dari variabel pelayanan bertanda positif. Hal ini berarti telah 250 
sesuai dengan prinsip-prinsip teori ekonomi, yaitu semakin baik tingkat pelayanan pada suatu bank maka semakin tinggi minat menabung seseorang ke bank tersebut, yg berarti semakin tinggi minat menabung seseorang semakin besar jumlah tabungan di Bank. Koefisien pelayanan menunjukkan nilai sebesar 1,028 yang bermakna bahwa semakin tinggi tingkat pelayanan sebesar 1,028 persen maka akan meningkatkan Jumlah tabungan FIRDAUS di PT. Bank Aceh Syariah Langsa sebesar 1,028 persen dan bersifat elastis.

Tabel 13: Hasil Estimasi Fungsi Jumlah Tabungan

\begin{tabular}{|c|r|r|r|r|c|}
\hline Variabel & Koefisien & Std. Error & Nilai t-ratio & Prob. & Signifikansi \\
\hline Cstimasi & -2.485927 & 2.332189 & -1.065920 & 0.2891 & \\
LOG(PLYN) & 1.028574 & 0.406176 & 2.532339 & 0.0130 & S \\
LOG(BH) & 1.425375 & 0.530881 & 2.684923 & 0.0085 & S \\
LOG(PNDPTN) & 0.737653 & 0.107504 & 6.861636 & 0.0000 & S \\
\hline
\end{tabular}

Keterangan: $S=$ signifikan pada $\alpha=5$ persen

\section{TS = tidak signifikan}

Koefisien parameter dari variabel bagi hasil bertanda positif. Hal ini berarti telah sesuai dengan prinsip-prinsip teori ekonomi, yaitu semakin tinggi tingkat bagi hasil maka semakin banyak nasabah ingin menabung dengan tingginya minat menabung seseorang maka jumlah tabungan akan meningkat. Koefisien bagi hasil menunjukkan nilai sebesar 1,425 yang bermakna bahwa setiap peningkatan bagi hasil sebesar 1,425 persen maka akan meningkatkan Jumlah tabungan FIRDAUS di PT. Bank Aceh Syariah Langsa sebesar 1,425 persen dan bersifat elastis.

Untuk koefisien parameter dari variabel pendapatan berpengaruh positif dan signifikan. Hal ini berarti telah sesuai dengan prinsip-prinsip teori ekonomi, pendapatan pendapatan seseorang semakin tinggi konsumsi mereka dalam memenuhi kebutuhannya, seperti membeli mobil mewah dan rumah. Dan seseorang dapat membatasi konsumsi mereka dengan menabung dan menabung tersebut untuk kebutuhan mereka yang akan datang, maka dalam hal ini semakin tinggi tingkat pendapatan seseorang semakin besar keinginan seseorang untuk menabung. Koefisien pendapatan menunjukkan nilai sebesar 0,737 yang bermakna bahwa setiap peningkatan pendapatan sebesar 0,737 persen maka akan meningkatkan Jumlah tabungan Firdaus di PT. Bank Aceh Syariah Langsa sebesar 0,737 persen dan bersifat inelastis. 
Ihtiyath Vol. 2 No. 2 Desember 2018

Berdasarkan hasil analisis pembahasan di atas maka penulis dapat mengambil kesimpulan bahwa:

1. Pelayanan mempunyai pengaruh positif dan signifikan terhadap jumlah tabungan FIRDAUS di PT. Bank Aceh Syariah Langsa, karena t-ratio sebesar 2,532 lebih besar dari t-tabel sebesar 1,984 atau prob sebesar 0,01 signifikan < 0,05.

2. Bagi hasil mempunyai pengaruh positif dan signifikan terhadap jumlah tabungan FIRDAUS di PT. Bank Aceh Syariah Langsa, karena t-ratio sebesar 2,684 lebih besar dari t-tabel sebesar 1,984 atau prob sebesar 0,00 signifikan < 0,05.

3. Pendapatan mempunyai pengaruh positif dan signifikan terhadap jumlah tabungan FIRDAUS di PT. Bank Aceh Syariah Langsa, karena t-ratio sebesar 6,861 lebih besar dari t-tabel sebesar 1,984 atau prob sebesar 0,000 signifikan < 0,05.

\section{DAFTAR PUSTAKA}

Agustianto, Percikan Pemikiran Ekonomi Islam: Respon terhadap Ekonomi Kontemporer. Disunting oleh Azhari Akmal Tarigan. (Bandung : FKEBI IAIN SU dan Cita Pustaka Media, 2002), h. 90.

Algifari, Analisis Regresi, Yogyakarta: BPFE, 1997.

Antonio, Muhammad Syafi'i, Bank Syari'ah : Dari Teori ke Praktik, disunting oleh Dadi M.H. Basri, Farida R. Dewi. Cet.1. Jakarta: Gema Insani Press, 2001.

Antonio, syafei, M., Bank Syari'ah Suatu Pengenalan Umum, jakarta: Tazkia Institute dan BI, 1999

Arikunto, Suharsimi, Prosedur Penelitian Suatu Pendekatan Praktek, Jakarta: Rineka Cipta, 1998.

Arisson Hendry dkk, Perbankan Syari'ah (Perspektif Praktisi),cet.1.Jakarta: Muamalat Institut,1999

Chapra, M. Umer, Al-Qur'an Menuju Sistem Moneter yang Adil, diterjemahkan dari judul asli : Towards a just Monetery System, Yogyakarta: PT. Dana Bhakti Prima Yasa, 1997

Depag RI, Al-Qur'an dan Terjemahnya Al-Jumanatul ‘Ali, Bandung: J-ART, 2004.

Himpunan Undang-undang, keputusan Presiden, Qanun, intruksi Gubernur dan Edaran Gubernur berkaitan pelaksanaan Syari'at Islam, Dinsyar

NAD: 2008. 
Muhammad Safri Antoni: Pengaruh Kualitas Pelayanan

Djarwanto \& Subagyo, Pangestu, Statistik Induktif, Yogyakarta: BPFE, 1993.

Gunara, Thorik \&Hardiono, U.S., Marketing Muhammad, Bandung: Takbir Publishing House, 2006

Peraturan Gubernur (pergub) Aceh Nomor 46 Tahun 2009 tentang "Penggunaan sebutan nama Aceh dan gelar pejabat pemerintahan dalam tata naskah dinas di Lingkungan Pemerintah Aceh"

Habib Nazir, Ensiklopedi Ekonomi dan Perbankkan Syari'ah, Bandung Kaki Langit, 2004

Hakim, Abdul, Statistika Deskriptif untuk Ekonomi dan Bisnis, Yogyakarta: Ekonisia, 2001.

Indriantoro, Nur \& Supomo, Bambang, Metodologi Penelitian Bisnis, Yogyakarta: BPFE, 1999.

Jabir, Taha, Bisnis Islam (Terjemahan), Yogyakarta: Ak Group, 2005.

Kasmir. Manajemen Perbankan. Jakarta:Rajawali Press.2000

Kotler, Philip, Manajemen Pemasaran, Jakarta: Prenhallindo, 1997.

Lupiyoadi, Rambat, Manajemen Pemasaran Jasa, Jakarta: Salemba Empat, 2001.

Muhammad, Perkembangan Bank Syari'ah, Yogyakarta :UPP AMP YKPN, 2002

Santoso, Singgih, SPSS Statistik Multivariat, Jakarta: Elek Media Komputindo, 2002.

Singarimbun, Masri \& Effendi, Sofian, Metodologi Penelitian Survei, Jakarta: Pustaka LP3ES, 1989.

Sugiyono, Statistik NonParametrik untuk Penelitian, Bandung: Alfabeta, 1999.

Sudardjat Ilyda, Faktor-faktor yang Mempengaruhi Simpanan Mudharabah pada Bank Syari'ah di Sumatera Utara, (Tesis MSi, Universitas Sumatera Utara, Medan, 2006

Supranto, Johanes, Pengukuran Tingkat Kepuasan Pelanggan (Jakarta: Rineka Cipta, 1997

Tatik Suryani, Sri Lestari, \& Wiwik Lestari, “Analisis Pelayanan Mutu Total dan Pengaruhnya Terhadap Kinerja Usaha Perbankan di Indonesia", Surabaya: Jurnal Ekonomi dan Bisnis Indonesia, No. 3, 2001.

Tim Pengembangan Perbankan Syari'ah IBI, Konsep, produk dan Implementasi Operasion- 
al Bank Syari'ah, Jakarta : Djambatan,2001

Tjiptono, Fandy, Manajemen Jasa, Yogyakarta: Andi Offset, 1996.

-, Prinsip-prinsip Total Quality Service, Yogyakarta: Andi Offset, 1997.

, Strategi Pemasaran, Yogyakarta: Andi Offset, 1995.

Wahyuningsih, Anis, Analisa Tingkat Kepuasan Konsumen Berdasarkan Kualitas

Pelayanan Pada Rumah Sakit Umum Kabupaten Karanganyar, Surakarta: Tesis Fakultas Ekonomi Program Studi Manajemen UMS, 2002.

Rahman, Afzalur, Doktrin Ekonomi Islam, diterjemahkan dari judul asli : Economic Doctrines of Islam, Jogjakarta: PT. Dana Bhakti Wakaf, 1996.

, Bank Syari'ah : Bagi Bankir \& Praktisi, diterbitkan atas kerjasama Bank Indonesia dan Tazkia Institut, Jakarta, 1999.

, Bank Syari'ah : Wacana Ulama \& Cendikiawan. Jakarta: Central Bank of Indonesia and Tazkia Institute, 1999. 